\title{
26. Ahol a különleges jogrend egyáltalán nem is különleges: az amerikai modell
}

\author{
BÉRES NÓRA \\ 1. A különleges jogrend \\ alkotmányos és törvényi szintü szabályozása, esetkörei
}

\author{
Hasonlóan néhány európai alkotmányhoz, az Egyesült Államok alkotmánya lényegében \\ egyáltalán nem tartalmaz rendelkezéseket a különleges jogrendre nézve. ${ }^{1}$ Ahogyan azt
}

I Noha az amerikai alkotmány az európai szabályozási logikával összecsengő különleges jogrendi esetköröket nem sorakoztat fel, az I. cikk 8. \$-a a Kongresszus hatáskörei között említi az USA közös védelmét, a hadüzenet küldését, valamint a milícia szervezetére, fegyverzetére és fegyelmére vonatkozó rendelkezések kibocsátását, valamint a milícia Egyesült Államok szolgálatában álló részének irányítását, fenntartva az egyes államok jogát a tisztek kinevezésére és a milícia kiképzésének irányítására a Kongresszus által megállapított fegyelmi renddel összhangban. Továbbá az I. cikk 10. \$-a azt is kimondja, hogy a tagállamok a Kongresszus hozzájárulása nélkül nem folytathatnak háborút, kivéve a tényleges megtámadtatás esetét vagy olyan fenyegető veszélyt, amely nem teszi lehetôvé a késlekedést. E rendelkezések tartalmi szempontból a magyar terminológia szerinti hadiállapottal rokoníthatók - amely kifejezés egyébként sem itt, sem máshol nem szerepel az amerikai alkotmányban. Utóbbi kihirdetése a Kongresszus feladata. A II. cikk 2. \$-a akként folytatja, hogy „az elnök az Egyesült Államok szárazföldi haderejének és hajóhadának és az egyes államok milíciájának fóparancsnoka, amikor az utóbbiakat az Egyesült Államok tényleges szolgálatában alkalmazzák". Tehát míg a hadiállapottal analóg helyzet kinyilvánítása a Kongresszus kizárólagos hatáskörébe tartozik, a haderő tényleges vezetése az elnököt, a végrehajtó hatalmi ág fejét - és egyben államfőt - illeti meg. Az 1791-ben elfogadott Második és a Harmadik Alkotmánykiegészítések szintén a hadiállapottal analóg helyzethez tartozó rendelkezéseket tartalmaznak azzal, hogy utóbbit expressis verbis továbbra sem nevezik így. A Második Alkotmánykiegészítés szerint: „Mivel egy jól szervezett milícia szükséges a szabad állam biztonsága szempontjából, nem lehet a népnek a fegyverek birtoklásához és viseléséhez való jogát csorbítani.” A Harmadik Alkotmánykiegészítés pedig megállapítja, hogy „béke idején katonát csak a ház tulajdonosának hozzájárulásával lehet beszállásolni; háború idején is a beszállásolás a törvényben megállapított módon történik" (Farkas-Kelemen, 2020, 260. o.).

Dr. Béres Nóra, PhD, LLM

nora.beres@mfi.gov.hu

kutató (Mádl Ferenc Összehasonlító Jogi Intézet)

tanársegéd (Miskolci Egyetem Állam- és Jogtudományi Kar, Európai és Nemzetközi Jogi Intézet)

Béres, N. (2021) 'Ahol a különleges jogrend egyáltalán nem is különleges: az amerikai modell' in Nagy, Z., Horváth, A. (szerk.) A különleges jogrend és nemzeti szabályozási modelljei, 563-591. o. Budapest: Mádl Ferenc Öszszehasonlító Jogi Intézet.

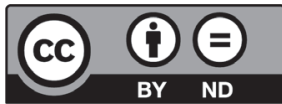

https://doi.org/10.47079/2021.nzha.kulon.4_26 
majd a későbbiek során láthatjuk, az amerikai szabályozás a különleges jogrend fogalmát az európai terminológia szerinti értelemben nem - pontosabban másképp - ismeri, ám jelen fejezet a szemléletes összehasonlító vizsgálat szempontjából kiterjesztő értelmezéssel a különleges jogrend kifejezést az amerikai megoldásokra is alkalmazza. Az Egyesült Államok szabályozása - szemben a kontinentális európai országok többségében alkalmazott úgynevezett dichotóm modellekkel ${ }^{2}$ - a monista modellt testesíti meg a különleges jogrend szabályozását, pontosabban „szabályozatlanságát” illetően. Ez alapján nem tehető egyértelmú különbség a kivételes állapot és a nem kivételes állapot között: a szabályozás különleges jogrendi jellegét az mutatja a rendes jogrendhez képest, hogy a kivételes állapotra adott válaszok rendkívüliek, a rendes jogrendi garanciákon túlnőnek. Az így hozott intézkedésekre jellemző, hogy azok sokszor ad hoc természetûek, és előzetesen nem szabályozott rendkívüli válaszok formájában jelennek meg. A monista modellre is igaz, hogy van intézkedésre jogosult (akár egyszemélyi) szerv, ${ }^{4}$ ebből adódóan pedig egyfajta hatalomkoncentráció figyelhető meg, ugyanakkor a bíróságok - különösen a Legfelsőbb Bíróság - a fékek és ellensúlyok elvét szem előtt tartva kulcsfontosságú szerephez jutnak: a bírói felülvizsgálat demokratikussági szempontból különösen felértékelődik, mert a kormányzati intézkedések esetleges „vadhajtásait" a bírósági kontrollmechanizmusnak kell „lemetszenie”. 5

A dichotóm modell és a monista modell melletti, illetve elleni érvek a részletesség és a normativitás együttes, ám mégis kizárólagos követelményei mentén vázolhatók fel, amit Csink Lóránd úgy jellemez, hogy „a különleges jogrend jogállami paradoxona”. ${ }^{6}$ Ez alapján a részletesség követelménye a dichotóm modell melletti érvként említhető, amelyet úgy lehetne összefoglalni, hogy mivel különleges jogrend idején egyértelmúen közhatalom gyakorlására kerül sor, és a közhatalom gyakorlásának jogi keretek közöttisége pedig alapvető jogállamisági követelmény - amely az államnak egyszersmind alkotmányos és nemzetközi jogi kötelezettsége ${ }^{7}$-, és mivel a jogállamiság elvéből az is következik, hogy az önkényes mérlegelés lehetőségét vissza kell szorítani, a különleges jogrendi szabályokat alkotmányos szinten kell rögzíteni akkor, ha a részletességnek eleget kívánunk tenni. Ezzel szemben a normativitás követelménye inkább a monista modell melletti érvkészletet gyarapítja. Tudniillik az is jogállamisági követelmény, hogy a jogi normák mindenkire, tehát a közhatalom gyakorlóira is vonatkozzanak, és ezeket az általános magatartási szabályokat - még ha nem is alkotmányos, de törvényi szinten - előzetesen állapítsák meg, mert csak így biztosítható a kiszámíthatóság, és várható el a normakövetés. Ám mivel a kivételes állapotot rendszerint

2 Elfogadva Mészáros Gábor álláspontját, a dichotómia itt azt jelenti, hogy bár a különleges jogrend és a rendes jogrend párhuzamosan érvényesülhet, az egyes konkrét intézkedések és jogintézmények szintjén azonban csak az egyik vagy másik ölthet testet. Mészáros, 2016, 37. o.

3 Mészáros, 2016, 37. o.

4 Mint ahogyan azt majd később láthatjuk, ezt a szerepet az Egyesült Államok esetén az elnök tölti be.

5 Mészáros, 2017, 100. 0.

6 Csink, 2017, 12-14. o.

7 Varga Zs., 2015, 11. o. 
előre nem látható társadalmi vagy természeti jelenségek idézik elő, ${ }^{8}$ valamennyi lehetséges forgatókönyv előzetes lefedése lehetetlen, tehát a különleges jogrend részletes és normatív szabályozásának kritériumai egyidejüleg nem teljesíthetôk.

Az 1787-ben elfogadott amerikai alkotmány szövege húen tükrözi az alkotmányozó atyák azon törekvését, hogy egyik hatalmi ág se kerüljön túlsúlyba a többihez képest. Ennek ellenére természetesen az Egyesült Államok szabályozása is elismeri annak szükségességét a hatékony válságkezelés és a jog reakcióképessége szempontjából, hogy veszélyhelyzetben (emergency) az intézkedésre jogosult, azaz az elnök kiterjesztett hatásköröket és nagyobb cselekvési szabadságot élvezhessen a békeidőben megszokottakhoz képest. A veszélyhelyzetben gyakorolható elnöki hatáskörök skálája kifejezetten széles, amelyek közül témánk szempontjából azok a különleges törvényi felhatalmazások (special statutory authorities) a legfontosabbak, amelyeket az elnök a saját maga vagy a Kongresszus által kihirdetett országos veszélyhelyzet (national emergency) esetén gyakorolhat.

A New York University kutatóintézete, a Brennan Center for Justice 2019. októberben publikált kutatása 123 olyan, törvényben szabályozott hatáskört különböztet meg, amelyet az amerikai elnök az általa kihirdetett országos veszélyhelyzetben gyakorolhat, továbbá ezen elnöki hatáskörök további 13 hatáskörrel bővülnek ki abban az esetben, ha az országos veszélyhelyzetet a Kongresszus rendelte el. Egyszerú matematikai számítással tehát arra juthatunk, hogy az elnököt 136 (!) féle különleges törvényi felhatalmazás illetheti meg akkor, amikor országos veszélyhelyzet kihirdetésére kerül sor. ${ }^{9}$

Jelen fejezet a különleges állapotokat szabályozó, valamint a különleges elnöki hatásköröket tartalmazó törvények közül csak a legfontosabbakkal foglalkozik részletesen, kiemelt figyelmet fordítva a közegészségi veszélyhelyzetre és a koronavírus-járványra. Ezek az alábbiak:

1944. évi törvény a közegészségügyi szolgáltatásokról;iº

— 1976. évi törvény az országos veszélyhelyzetről:;1

- 1988. évi törvény a katasztrófavédelemről és a veszélyhelyzetben való segítségnyújtásról ${ }^{12}$ (az úgynevezett Stafford-törvény); ;13

— az Egyesült Államok Kódexe ${ }^{14} 22$. cím: Külkapcsolatok:15

8 Csink, 2017, 8. o.

9 Brennan Center, 2019.

10 Public Health Service Act [42 U.S.C. \$247d].

11 National Emergencies Act [50 U.S.C. \$\$1601 et seq.]

12 Robert T. Stafford Disaster Relief and Emergency Assistance Act [42 U.S.C. \$\$ 5121 et seq.].

$13 \mathrm{Az}$ angol terminológia a törvényre "Stafford Act”-ként hivatkozik, tisztelegve a néhai Robert T. Stafford egykori republikánus politikus és vermonti szenátor előtt, akit a jogszabály atyjának tekintenek, így mi is ezt a rövidítést használjuk.

14 Az Egyesült Államok Kódexe [10 U.S.C. \$ 2808] általános és állandó, szövetségi szintû törvénygyüjtemény, amely tárgyak szerint tartalmazza az egyes címeket, és a képviselőház törvényi felülvizsgálati tanácsának irodája adja ki. Elérhető: www.govinfo.gov/help/uscode (Letöltve: 2020. december 10.).

15 U. S. Code [22 U.S.C. $\$ 2318$ (a)(1)]. 
— 2002. évi törvény a belbiztonságról:16

— 2006. évi törvény a Katrina hurrikán utáni veszélyhelyzet-kezelési reformról. ${ }^{17}$

Az alábbiakban az egyes törvények elfogadásuk időrendi sorrendje és nem a rájuk történt hivatkozások gyakorisága szerint kerülnek bemutatásra azzal, hogy ismételten hangsúlyozni kell: számos más jogszabályban és jogterületen ${ }^{18}$ is vannak még a témánkhoz szervesen kapcsolódó föderális szintû szabályok, mindazonáltal a teljesség igényével való bemutatásra törekvés jelen munka korlátai között lehetetlen vállalkozás volna.

\subsection{A közegészségügyi szolgáltatásokról szóló 1944. évi törvényés a közegészségi veszélyhelyzet}

A közegészségügyi szolgáltatásokról szóló 1944. évi törvény ${ }^{19}$ alapján az Egyesült Államok egészségügyért felelős minisztere (Secretary for Health and Human Services) közegészségi veszélyhelyzetet (public health emergency) rendelhet el. A közegészségi veszélyhelyzetre okot adó társadalmi és természeti jelenségek a gyakorlatban nagyon változatosak lehetnek, azaz nemcsak betegségek tartozhatnak ide, hanem például a közegészséget sértő vagy veszélyeztetô természeti katasztrófák is.

Ha csak 2020-at nézzük, az egészségügyért felelős miniszter 12 alkalommal hirdetett ki közegészségi veszélyhelyzetet e törvény alapján az egész Egyesült Államok vagy meghatározott tagállam(ok) területére nézve. Januárban a Puerto Rico-i földrengés, az opioidkrízis $^{20}$ és a koronavírus-járvány miatt rendelte el országos szinten. Áprilisban és júliusban az opioid-krízis és a koronavírus-járvány miatti közegészségi veszélyhelyzetet országos

16 Homeland Security Act [6 U.S.C. \$1 101].

17 Post Katrina Emergency Management Reform Act [6 U.S.C. \$ 601].

18 Ilyenek például a közegészségügy, az ingatlanok kisajátítása, a honvédelem, a kormánytisztviselők (kiterjesztően értelmezve, idesorolva a rendőröket, a hivatásos katonákat, a parti őrség tagjait stb.) foglalkoztatásának feltételei, a magántulajdon lefoglalása, a büntetőeljárás és a fogva tartás, a nemzetközi kapcsolatok (Brennan Center, 2019, 3-43. o.).

19 1944. évi közegészségügyi szolgáltatásokról szóló törvény 319. cikk (a) bekezdés: „Ha az egészségügyért felelős miniszter a népegészségügyi tisztviselőkkel folytatott egyeztetést követően úgy látja, hogy (1) egy betegség vagy orvosi rendellenesség, illetve (2) egy fertőző betegség jelentős elterjedése, biológiai terrortámadás vagy egyéb ok miatt közegészségi veszélyhelyzet áll fenn, akkor e közegészségi veszélyhelyzetre reagálva megfelelő intézkedéseket hozhat, beleértve támogatások odaítélését, költségtérítések kifizetését, szerződések megkötését és olyan vizsgálatok lefolytatását, amely utóbbiak a betegség vagy orvosi rendellenesség okát, kezelését vagy megelőzését szolgálják.".

20 2019-ben közel 50 ezer ember halálát okozta opioid-túladagolás az Egyesült Államokban. E fájdalomcsillapítókkal való visszaélés mintegy 78,5 milliárd dollár értékủ gazdasági terhet rótt az ország költségvetésére, beleértve az egyészségügyi költségeket, a kiesett munkaerőt, a kábítószerfüggők kezelését és a büntető igazságszolgáltatás költségeit. A jelenség mögött a gyógyszergyártók gazdasági haszonszerzési célja állt, amely arra ösztönözte őket, hogy ne hozzák nyilvánosságra az opioid okozta függőség valódi fokát. National Institute on Drug Abuse, elérhető: www.drugabuse.gov/drug-topics/opioids/opioid-overdose-crisis (Letöltve: 2020 . december 15.). 
szinten meghosszabbította. 2020 augusztusában a kaliforniai erdőtüzek és a Laura hurrikán miatt hirdetett ki a miniszter közegészségi veszélyhelyzetet, előbbi miatt Kalifornia államban, utóbbi miatt Louisiana államban és Texas államban. Szeptemberben szintén erdőtüzek miatt Oregon államban hirdette ki, illetve októberben ismételten meghosszabbította az egészségügyért felelős miniszter a közegészségi veszélyhelyzetet az egész Egyesült Államokban az opioid-krízis és a koronavírus-járvány miatt.

A közegészségi veszélyhelyzet a veszélyhelyzet fennállásáig vagy 90 napig tarthat, ám ezt az időtartamot az egészségügyért felelős miniszter meghosszabbíthatja (a fenti adatokból is kitűnik, hogy a megújítás hozzávetőlegesen háromhavonta történik). A közegészségi veszélyhelyzet elrendeléséról a Kongresszust 48 órán belül értesíteni kell, továbbá tájékoztatni kell az érintett szerveket, beleértve a Belügyminisztériumot, az Igazságügyi Minisztériumot és a Szövetségi Nyomozó Irodát (FBI). ${ }^{21}$

A közegészségi veszélyhelyzet elrendelésének gyakorisága a korábbi években is hasonlóan magas volt, illetve jelenleg is számos közegészségi veszélyhelyzet van párhuzamosan hatályban, ezekből adódóan pedig arra következtethetünk, hogy egy, a gyakorlatban rendszeresen alkalmazott jogintézményről van szó, amely Magyarország Alaptörvényének különleges jogrendi koncepciójával, ${ }^{22}$ annak ultima ratio jellegével nehezen állítható párhuzamba. ${ }^{23}$

\subsection{Az Egyesült Államok Kódexe: külkapcsolatok és az előre nem látható veszélyhelyzet}

Az Egyesült Államok Kódexe ${ }^{24}$ alapján, amelyet 1961-ben fogadtak el, az elnök elrendelheti a Védelmi Minisztérium (Department of Defense) előirányzatainak lehívását, állományának bevetését, szolgáltatásainak igénybevételét, valamint hadtudományi oktatást és katonai kiképzést más államnak vagy nemzetközi szervezetnek történő katonai, gazdasági, békefenntartói, terrorizmus elleni és proliferáció elleni segítségnyújtás céljából azzal, hogy ennek éves összege a 100 millió amerikai dollárt nem haladhatja meg.

E jogszabályhely az elrendelés lehetséges okaként az előre nem látható veszélyhelyzetet (unforeseen emergency) jelöli meg, ám annak fogalmát nem bontja ki. Továbbá ugyanezen cikk rendelkezik arról, hogy e szabályozás csupán szubszidiárius jellegú, azaz csak akkor lehet rá hivatkozni, ha a fegyverexport ellenőrzéséről szóló törvényben ${ }^{25}$ használt veszélyhelyzet-fogalom feltételei nem teljesülnek. Az Egyesült Államok Kódexének e helyütt tárgyalt rendelkezése értelmében 1988 és 2017 között 57 alkalommal hirdettek ki előre nem látható

21 U. S. Department of Health and Human Services (2020) Public Health Emergency Declarations: www.phe. gov/emergency/news/healthactions/phe/Pages/default.aspx (Letöltve: 2020. december 9.).

22 Till, 2018, 1. o.

23 Legfeljebb az egészségügyről szóló 1997. évi CLIV. törvény szerinti egészségügyi válsághelyzet vagy a katasztrófavédelemről és a hozzá kapcsolódó egyes törvények módosításáról szóló 2011. évi CXXVIII. törvény szerinti katasztrófaveszély nyújthat releváns összehasonlítási alapot.

24 Az Egyesült Államok Kódexe 22. cím 32. fejezet II. alfejezet II. rész (a) bekezdés (1) pont.

25 Arms Export Control Act [22 USC \$\$ 2751 et seq.]. 
veszélyhelyzetet. Például 2014-ben az USA e törvénye alapján támogatta Franciaország Malival, Csáddal és Nigerrel szembeni terrorizmus elleni tevékenységét. ${ }^{26}$

\subsection{Az országos veszélyhelyzetről szóló 1976. évi törvény és az országos veszélyhelyzet}

Az amerikai elnök országos veszélyhelyzetet (national emergency) az 1976. évi, az országos veszélyhelyzetről szóló törvény ${ }^{27}$ alapján ${ }^{28}$ hirdethet ki, ${ }^{29}$ amire rendkívül széles diszkrecionális jogköre nyílik, hiszen a törvényben - amely egyébként meglehetősen rövid - még arra nézve sem találhatunk korlátozó rendelkezéseket, hogy milyen típusú társadalmi vagy természeti jelenségek idézhetnek elő veszélyhelyzetet. Ugyanakkor az országos veszélyhelyzet kihirdetésekor az elnöknek annak törvényi jogalapját is megjelölve előre meg kell határoznia, hogy a veszélyhelyzet alatt mely hatásköreit fogja gyakorolni, és a Kongresszusnak minden hatodik hónapban be kell számolnia a veszélyhelyzettel kapcsolatos kiadásokról.

Bár e törvény értelmében az országos veszélyhelyzet legkésőbb egy év után ipso iure megszû́nik,,$^{30}$ az elnöknek jogában áll ezt az időtartamot meghosszabbítani, és ez utóbbi - gyakorlatilg rutinszerúen - elő is fordul. Noha az országos veszélyhelyzetről szóló törvény felhatalmazza a Kongresszust, hogy az elnök által kihirdetett országos veszélyhelyzetnek véget

26 Brennan Center, 2019.

27 A törvény elfogadásának időpontja beszédes: a vietnámi háború és a Watergate-ügy után elengedhetetlennek tûnt, hogy az elnök és a Kongresszus szerepkörét határozottabb törvényi kontúrokkal vonják meg. Constitutional Daily, The Debate Over Emergency Powers and the Border Wall, elérhető: https://constitutioncenter. org/blog/the-debate-over-emergency-powers-and-the-border-wall (Letöltve: 2020 . december 12.).

28 1976. évi országos veszélyhelyzetről szóló törvény 201. cikk (a) bekezdés: „A Kongresszus azon törvényei értelmében, amelyek engedélyezik bármely különleges vagy rendkívüli hatalom gyakorlását országos veszélyhelyzet kihirdetése esetén, az elnök jogosult országos veszélyhelyzet kihirdetésére. Az ilyen kiáltványt haladéktalanul továbbítják a Kongresszusnak, és közzéteszik a Szövetségi Nyilvántartásban.”.

$29 \mathrm{Az}$ országos veszélyhelyzet kihirdetése pro forma végrehajtási utasítással (executive order) vagy kiáltványnyal (proclamation) történik. A végrehajtási utasítások nem jogszabályok, címzettjük a törvényhozás, tehát a Kongresszusnak kell végrehajtani őket. A végrehajtási utasításokat a Kongresszusnak nem kell jóváhagynia, és nem is tudja egyszerúen hatályon kívül helyezni őket. A Kongresszus azonban elfogadhat olyan jogszabályokat, amelyek megnehezítik vagy akár ellehetetlenítik az utasítás végrehajtását, például a költségvetési finanszírozás megvonásával. Csak a mindenkori hivatalban lévő elnök dönthet egy végrehajtási utasítás hatályon kívül helyezéséról úgy, hogy kiad egy erre vonatkozó másik végrehajtási utasítást. A végrehajtási utasításokkal szemben a kiáltványok valódi jogszabályok, de valódi kötőerôvel csak attól fogva rendelkeznek, ha a Kongresszus jóváhagyta őket. Lásd az American Bar honlapját: www.americanbar.org/groups/ public_education/publications/teaching-legal-docs/what-is-an-executive-order-/ (Letöltve: 2020. december 9.), valamint a Deccan Herald honlapját: www.deccanherald.com/international/explainer-what-does-apresidential-proclamation-mean-852924.html (Letöltve: 2020 . december 9.).

30 1976. évi országos veszélyhelyzetről szóló törvény 202. cikk (d) bekezdés: „Az elnök által e törvény alapján kihirdetett és korábban másként meg nem szüntetett országos veszélyhelyzet kihirdetésének évfordulóján szűnik meg, ha az elnök az egyes évfordulót megelőző 90 napos időszakon belül nem teszi közzé a Szövetségi Nyilvántartásban azt, és nem értesíti a Kongresszust arról, hogy az országos veszélyhelyzet az évforduló után is fennmarad.". 
vessen, ${ }^{31}$ erre az elmúlt 40 évben mindössze egyszer volt példa. (Erról részletesebben lásd a 4. pontot.)

A törvény 1978-ban történt hatálybalépése óta összesen 69 alkalommal hirdettek ki országos veszélyhelyzetet az Egyesült Államokban, ebből pedig 40 (!) jelenleg is hatályban van; ${ }^{32}$ így például a legelső, Jimmy Carter által kihirdetett országos veszélyhelyzet, amely az iráni kormány tulajdonszerzését korlátozza (legutoljára 2020. november 12-én újították meg), ${ }^{33}$ vagy például több mint 26 éve van hatályban a tömegpusztító fegyverek proliferációja miatt Bill Clinton által elrendelt országos veszélyhelyzet (legutóbb szintén 2020. november 12-én újították meg). ${ }^{34}$ Úgyszintén a 2001. szeptember 11-i terrortámadások után George W. Bush által bevezetett országos veszélyhelyzetet sem helyezték még hatályon kívül (utoljára 2020. szeptember 10-én hosszabbították meg). ${ }^{35} \mathrm{~A}$ koronavírus-járvány miatti, jelenleg is hatályos országos veszélyhelyzetet 2020. március 13-án hirdette ki Donald Trump. Az országos veszélyhelyzet közegészségi okokból történő elrendelése az előző kormányzati ciklus gyakorlatát figyelembe véve sem példátlan: Barack Obama a HiN1-influenzajárvány idején is országos veszélyhelyzetet hirdetett ki 2009ben $^{36}$ (amely egyébként az elrendelés első évfordulóján - megújítás hiányában - a törvény erejénél fogva megszúnt).

\subsection{A Stafford-törvény és a veszélyhelyzet, az elemi katasztrófa, valamint a veszélyhelyzeti készültség}

A Szövetségi Veszélyhelyzet-kezelési Ügynökség (Federal Emergency Management Agency) a központi szintû válságkezelés első számú letéteményese, amelyre a törvényi szintủ szabályokat a Stafford-törvény állapítja meg. A Stafford-törvény hatálybalépésével a szövetségi szintû́ válságkezelés normatív kereteit felállító 1974. évi katasztrófavédelmi törvényt ${ }^{37}$ váltotta fel. Már elöljáróban érdemes rögzíteni, hogy e törvény tárgyi hatálya a külső támadásokat, a nukleáris baleseteket, valamint a kémiai, biológiai vagy radioaktív incidenseket nem öleli fel.

31 Erre a Kongresszusnak úgynevezett közös rendelettel nyílik lehetősége, amelyet a képviselőház és a szenátus együttesen hoznak meg. [1976. évi országos veszélyhelyzetről szóló törvény 202. cikk (a) bekezdés (1) pont: „Az elnök által e törvény alapján kihirdetett országos veszélyhelyzet megszủnik, ha a veszélyhelyzetet közös rendelettel megszüntetik."].

32 Brennan Center, 2020.

33 Blocking Iranian Government Property, E.O. 12170, November 14, 1979, 85 FR 72895.

34 Proliferation of Weapons of Mass Destruction, E.O. 12938, November 14, 1994, 85 FR 72897.

35 Declaration of National Emergency by Reason of Certain Terrorist Attacks, Proc. 7463, September 14, 2001, 85 FR 56467.

36 Declaration of a National Emergency with Respect to the 2009 H1Ni Influenza Pandemic, Proc. 8443, October 23, 2009, 74 Fed. Reg. 55439-55440.

37 Disaster Relief Act, Kahn-Barondess, 2008, 913. o. 
A különleges jogrendi kategóriák tekintetében a Stafford-törvény háromféle klasszifikációt határoz meg, így elsőként a veszélyhelyzet (emergency) fogalmát rögzíti. ${ }^{38} \mathrm{~A}$ normaszöveget olvasva kitûnik, hogy a veszélyhelyzet fennállásának megállapítása az elnök mérlegelési jogkörébe tartozik, továbbá, hogy kihirdetésére csak taxatíve meghatározott célból (az emberi élet megóvása, a tulajdon, a közegészség és a közbiztonság védelme, valamint katasztrófahelyzet okozta fenyegetés csökkentése vagy elhárítása) kerülhet sor, és hogy a szövetségi szintú támogatás a tagállami és helyi önkormányzati intézkedésekhez képest szubszidiárius jellegú.

Ezt követően a törvény az elemi katasztrófa (major disaster) definícióját határozza meg. ${ }^{39}$ A rendelkezés tartalma a veszélyhelyzetet definiáló bekezdésben foglaltakhoz hasonlít abban, hogy az elemi katasztrófa bekövetkeztének megállapítása szintén az elnök mérlegelési jogkörébe tartozik, és a kihirdetésre itt is csak meghatározott célokból kerülhet sor (a károk, veszteségek, nehézségek és szenvedések enyhítése), valamint a szövetségi szintú támogatás a tagállami, helyi önkormányzati és katasztrófavédelmi szervek intézkedéseihez képest ismét szubszidiárius jellegú, ellenben normatív többletként jelentkezik, hogy e rendelkezés a kihirdetésre okot adó eseteket taxatíve felsorolja (hurrikán, tornádó, vihar, dagály, hullámverés, szökőár, cunami, földrengés, vulkánkitörés, földcsuszamlás, sárcsuszamlás, hóvihar, szárazság, tűzvész, árvíz vagy robbanás). Mind a természeti csapások, mind az emberi tevékenység által okozott elemi katasztrófák (például emberi szándékosságból vagy gondatlanságból okozott erdőtüzek) e rendelkezés tárgyi hatálya alá tartoznak.

Azon túl, hogy mind a veszélyhelyzet, mind az elemi katasztrófa fennállásának kihirdetése az elnök hatáskörébe tartozik, a Stafford-törvény további cikkei ${ }^{40}$ alapján látható, hogy az elemi katasztrófa és a veszélyhelyzet fennállása tekintetében az elnök figyelmének felhívása és a különleges jogrendre vonatkozó kérelem előterjesztése az érintett tagállam kormányzójának hatáskörébe tartozik.

Mint ahogyan azt fentebb már említettük, a veszélyhelyzeti készültséggel a Staffordtörvény a VI. cím alatt foglalkozik. A szabályozás érdekessége, hogy míg a veszélyhelyzet és az elemi katasztrófa fogalmát az amerikai jogalkotó már a törvény elején, az I. cím alatt

38 Stafford-törvény 102. cikk (1) bekezdés: „E törvény értelmében veszélyhelyzet alatt valamennyi olyan helyzetet vagy esetet érteni kell, amelynek kapcsán az elnök úgy határoz, hogy az emberi élet megóvása, a tulajdon, a közegészség és a közbiztonság védelme, valamint katasztrófahelyzet okozta fenyegetés csökkentése vagy elhárítása érdekében szövetségi szintú támogatás nyújtása szükséges az Egyesült Államok bármely pontján a tagállamok és helyi önkormányzatok kapacitásának megerősítéséhez.".

39 Stafford-törvény 102. cikk (2) bekezdés: „E törvény értelmében »elemi katasztrófa« alatt valamennyi olyan komoly és súlyos kárt okozó természeti katasztrófát - így hurrikánt, tornádót, vihart, dagályt, hullámverést, szökőárat, cunamit, földrengést, vulkánkitörést, fölcsuszamlást, sárcsuszamlást, hóvihart vagy szárazságot - és - tekintet nélkül keletkezésük okára - valamennyi túzvészt, árvizet vagy robbanást érteni kell, amelynek kapcsán az elnök úgy határoz, hogy a károk, veszteségek, nehézségek és szenvedések enyhítése érdekében az e törvény szerinti elemi katasztrófák során nyújtandó támogatás nyújtása szükséges az Egyesült Államok bármely pontján a tagállamok, helyi önkormányzatok és katasztrófavédelmi szervek rendelkezésre álló kapacitásának és forrásainak megerősítéséhez.".

40 Stafford-törvény 401 . cikk a) pont és 501 . cikk a) pont. 
meghatározza, addig a veszélyhelyzeti készültség (emergency preparedness) kategóriája csak később ${ }^{41}$ túnik fel először, aminek célja, hogy a szövetségi kormányzat és a tagállamok együttesen viseljék a felelősséget az életet és tulajdont fenyegetô veszélyekre való felkészülés során. A törvény meghatározza a veszély (hazard), ${ }^{42}$ illetve a természeti katasztrófa ${ }^{43}$ fogalmát is. E cím harmadik lényegi fogalommeghatározása a veszélyhelyzeti készültség definíciója, amely alatt minden olyan tevékenység és intézkedés értendő, amely a veszélyre való felkészülés során vagy a veszély kiváltotta hatások visszaszorítása, valamint a civil lakosságnak biztosítandó közszolgáltatások és polgári létesítmények helyreállítása érdekében szükséges. A Stafford-törvény értelmében a veszélyhelyzeti készültséget nem az elnök, hanem a Kongresszus állapítja meg, amelyet mind megelőző jelleggel, mind a veszély fennállása alatt és után is kihirdethet.

1953 és 2014 között évente (!) átlagosan 35,5 elemi katasztrófát hirdettek ki az elnökök a Stafford-törvény és elődje, a katasztrófavédelemről szóló 1954. évi törvény alapján, illetve 1974 és 2014 között évente átlagosan kilencszer hirdettek ki veszélyhelyzetet a Staffordtörvény 102. cikk (1) bekezdése szerint. ${ }^{44}$

\subsection{A 2002. évi belbiztonsági törvény és az elemi katasztrófa, valamint a terrorhelyzet}

Reagálva a 2001. szeptember 11-i New York-i és a Pentagont érő terrortámadásokra, az Egyesült Államok Kongresszusa új belbiztonsági törvényt fogadott el, ${ }^{45}$ amellyel az addig a végrehajtó hatalmi ághoz tartozó számos feladat- és hatáskört egy új központi kormányzati végrehajtó szervre, a Belbiztonsági Minisztériumra (Department of Homeland Security) ruháztak át. A Belbiztonsági Minisztérium alá tartozik többek között a Szövetségi Veszélyhelyzet-kezelési Ügynökség, az Egyesült Államok Vám- és Pénzügyőrsége (US Customs Service), Állat- és Növényegészségügyi Ellenőrző Szerve (Animal and Plant Health Inspection Service), valamint Bevándorlási és Állampolgársági Hivatala (Immigration and Naturalization Service). ${ }^{46}$ A Belbiztonsági Minisztérium elsődleges feladata a terrortámadások elhárítása, illetve utóhatásainak csökkentése.

41 Stafford-törvény 601. cikk.

42 Stafford-törvény 602. cikk a) (1) bekezdés: „Veszély alatt az olyan veszélyhelyzetet és katasztrófát kell érteni, amely (A) természeti csapásból, illetve (B) balesetből vagy emberi tényezőből ered.”.

43 Stafford-törvény 602. cikk a) (2) bekezdés: „Természeti katasztrófa alatt valamennyi, az Egyesült Államok bármely pontján előforduló hurrikánt, tornádót, vihart, árvizet, dagályt, hullámverést, szökőárat, cunamit, földrengést, vulkánkitörést, fölcsuszamlást, sárcsuszamlást, hóvihart, szárazságot, túzvészt és egyéb katasztrófát kell érteni, amely a polgári lakosság tulajdonában anyagi kárt vagy személyében testi sérülést okoz vagy okozhat.".

44 Brennan Center, 2019.

45 Továbbá ekkor fogadták el az úgynevezett patriótatörvényt is: Uniting and Strengthening America by Providing Appropriate Tools Required to Intercept and Obstruct Terrorism Act (USA Patriot Act) [Public L. No. 107-56-OCT. 26, 2001].

46 U. S. Department of Homeland Security: History: Who Became Part of the Department? Elérhető: www.dhs.gov/ xabout/history/editorial_0133.shtm (Letöltve: 2020 . december 1.). 
A különleges jogrendi kategóriák tekintetében a 2002. évi belbiztonsági törvény viszszautal ${ }^{47}$ a Stafford-törvényre, ${ }^{48}$ átvéve az elemi katasztrófa fogalmát. Azonban új törvényi terminológiát teremt, amikor kimondja a terrorhelyzet (terrorism) fogalmát. ${ }^{49} \mathrm{~A}$ belbiztonsági törvénnyel továbbá felállították a belbiztonsági miniszteri tisztséget (Secretary of Homeland Security), akinek egy 2003 februárjában elfogadott elnöki rendelet ${ }^{50}$ elsődleges feladatául az elemi katasztrófák során a szövetségi szintú fellépés koordinálását jelölte meg (beleértve a nukleáris baleseteket és terrortámadásokat is).

\subsection{A 2006. évi Katrina hurrikán utáni veszélyhelyzet-kezelési reformról szóló törvény és a katasztrofális esetek}

E törvény elfogadásával az Egyesült Államok Kongresszusa a Katrina hurrikán okozta kihívásokra igyekezett hatásos választ adni. Mint ahogyan azt a jogszabály elnevezése is mutatja, tulajdonképpen egy reformtörvényről van szó, amely mind a Stafford-törvényt, mind a belbiztonsági törvényt módosította, és felállította az Egyesült Államok Veszélyhelyzet-kezelési Hatóságát (Emergency Management Authority).

A 2006. évi Katrina hurrikán utáni veszélyhelyzet-kezelési reformról szóló törvény elemi katasztrófák esetén kiterjeszti az elnök hatáskörét az előzetes evakuálás elrendelésére és a kormányzati segítségnyújtás előzetes kérelem nélküli folyósítására, valamint széles körben felülvizsgálja a válságkezelési rendelkezéseket azzal, hogy a Szövetségi Veszélyhelyzet-kezelési Ügynökséget továbbra is a Belbiztonsági Minisztérium szervezetrendszerébe tagolja. A törvény bevezeti a katasztrofális eset (catastrophic incident) fogalmát, ezzel is tovább bővítve a különleges jogrend jellegú kategóriák halmazát.

47 2002. évi belbiztonsági törvény 2. cikk (11) bekezdés.

48 Stafford-törvény 102. cikk (2) bekezdés.

49 2002. évi belbiztonsági törvény 11. cikk (15) bekezdés: „Terrorizmus alatt minden olyan tevékenységet érteni kell, ami (A) olyan cselekményt jelent, amely (i) veszélyes az emberi életre, vagy potenciálisan rombolhatja a létfontosságú infrastruktúrát vagy a kulcsfontosságú erőforrásokat; és (ii) megsérti az Egyesült Államok vagy bármely állam vagy az Egyesült Államok bármely más alegységének büntető törvényeit; és (B) úgy tủnik, hogy (i) célja a polgári lakosság megfélemlítése vagy kényszerítése; (ii) a kormány politikájának megfélemlítéssel vagy kényszerrel történő befolyásolása; vagy (iii) a kormány magatartásának tömegpusztítással, merénylettel vagy emberrablással történő befolyásolása.".

50 Homeland Security Presidential Directive-5, February 28, 2003, Subject: Management of Domestic Incidents. Elérhető: www.dhs.gov/sites/default/files/publications/Homeland\%20Security\%20Presidential\%20 Directive\%205.pdf (Letöltve: 2019. december 7.). 


\section{Az alapjogok korlátozására vonatkozó szabályok különleges jogrend idején}

Az Amerikai Egyesült Államok emberi jogokhoz füződő viszonya meglehetősen sajátos. E viszonyról sokat elárul, ha gyorsan számba vesszük azokat a legfontosabbnak mondható egyetemes és regionális emberi jogi instrumentumokat, amelyeknek az USA nem részes állama: a Gazdasági, Szociális és Kulturális Jogok Nemzetközi Egyezségokmányának (1966), a nőkkel szembeni megkülönböztetés minden formájának felszámolásáról szóló egyezménynek (1979), a Gyermekjogi Egyezménynek (1989), a migráns munkavállalók és családtagjaik jogainak védelméről szóló nemzetközi egyezménynek (1990), a Nemzetközi Büntetőbíróság Római Statútumának (1998), a fogyatékossággal élő személyek jogairól szóló egyezménynek (2006), az erőszakos körülmények között eltűnt személyek védelméről szóló nemzetközi egyezménynek (2006), ${ }^{51}$ valamint az Emberi Jogok Amerikai Egyezményének (1969). (Utóbbitól való távolmaradásának okát például az Egyesült Államok policyjelleggel azzal indokolta, hogy belső jogvédelmi rendszere sokkal hatékonyabb, mint a regionális kontrollmechanizmus.) $)^{52}$ A legfontosabb emberi jogi nemzetközi szerződések közül tehát az USA csupán a Polgári és Politikai Jogok Nemzetközi Egyezségokmányát (1966, a továbbiakban: Egyezségokmány vagy PPJNE) ratifikálta, igaz, azt is csak a PPJNE megszületése után 26 évvel, 1992-ben..$^{53}$ Mivel azonban a PPJNE megsértése miatt egyéni panasszal csak azon államok ellen lehet élni az Emberi Jogok Bizottsága előtt, amelyek ratifikálták az Egyezségokmány Első Fakultatív Jegyzőkönyvét (1966), azt mondhatjuk, hogy az emberi jogok, illetve alkotmányos alapjogok legmagasabb kontrollmechanizmusa egyéni ügyekben - számba véve a nemzetközi fórumok joghatóságának fenti okok miatti hiányát - az Egyesült államok Legfelsőbb Bírósága. Továbbá az amerikai szabályozás rendhagyó jellegéből adódik az a sajátos körülmény, hogy a különleges jogrend idején történő alapjog-korlátozásról egyetlen törvény sem rendelkezik részletesen, így ez is azt indokolja, hogy e témában mindenképpen a Legfelsőbb Bíróság joggyakorlatát kell alapul venni. A soron következő jogesetek tehát a következő szempontrendszer szerint kerülnek bemutatásra: egyrészt érintjük a Legfelsőbb Bíróság járványkezeléshez kapcsolódó ügyeit, másrészt pedig olyan ügyeket tárgyalunk, amelyek a hadiállapothoz kapcsolódnak.

Ami a járványkezelés kérdését illeti, a Legfelsőbb Bíróság első idekapcsolódó esete a Compaigne Francaise de Navigation a Vapeur v. Louisiana Board of Health ügy ${ }^{54}$ volt 1902-ben,

51 The Advocates for Human Rights, Human Rights \& the U. S. How Has the United States Handled Human Rights Issues in the Past \& Today? Elérhető: www.theadvocatesforhumanrights.org/human_rights_and_the_united_ states (Letöltve: 2020. december 20.).

52 Raisz, 2010, 289. o.

53 United Nations Treaty Collection. Elérhető:https://treaties.un.org/pages/ViewDetails.aspx?src=TREATY\&mtdsg_ no=IV-4\&chapter=4\&clang=_en (Letöltve: 2020 . december 22.).

54 U. S. Supreme Court, Compaigne Francaise de Navigation a Vapeur v. Louisiana Board of Health, 186 U.S. 380 (1902). 
amelyben megállapítást nyert, hogy nem ütközik a Tizennegyedik Alkotmánykiegészítésbe az a louisianai jogszabály, amely járványhelyzetben elrendeli a kötelező karantént. Az eset tényállása szerint 1898-ban a Britannia gőzös először Palermóból Marseille-be, majd onnan New Orleansba hajózott. Mielőtt úti célját elérte volna, a hajó legénysége és 408 utasa - akik túlnyomó többségben olasz bevándorlók voltak - járványügyi ellenőrzésen esett át egy, a Mississippi folyón található állami karanténállomáson, ahol mindenkit egészségesnek nyilvánítottak. Ennek ellenére két nappal később a hatóságok nem engedték a gőzöst a szárazföldön kikötni, mivel New Orleans egészségügyi hatósága a várost vesztegzár alá helyezte. Az intézkedés célja az volt, hogy megfékezzék a sárgalázat és annak Európából történő, ismétlődő behurcolását. A Compaigne Francaise de Navigation a Vapeur hajótársaság, vagyis az ügy felperese ellenben többek között azzal érvelt, hogy az intézkedés valódi célja a bevándorlók partra szállásának megakadályozása volt, és az intézkedés a hajótársaság tisztességes eljáráshoz való jogát, illetve az alkotmány kereskedelmi klauzuláját ${ }^{55}$ is sérti. Az ügyben a Legfelsőbb Bíróság kimondta, hogy a tagállamok hatáskörében áll a karantén elrendelése közegészségi okokból addig, amíg a Kongresszus ezzel ellentétes tartalmú jogszabályt nem hoz, ebből levezetve pedig a bíróság a felperes által benyújtott fellebbezést elutasította.

Az amerikai Legfelsőbb Bíróság járványkezeléshez kapcsolódó második és egyben talán a legfontosabb, mérföldkőnek számító döntése minden bizonnyal a Jacobson v. Massachusetts ügy ${ }^{56} 1905$-ből, amelyben az alkotmányvédő fórum kimondta, hogy a tagállamok hatáskörében áll kötelező védőoltásokról szóló jogszabályokat alkotni és karantént elrendelni, továbbá hogy az egyén szabadsága nem abszolút, és hogy ezért adott esetben alá kell vetnie magát a tagállami hatóságok intézkedéseinek. Az ügy tényállása szempontjából releváns, hogy akkoriban Massachusetts egyike volt annak a 11 tagállamnak, amelyekben a helyi önkormányzatok kötelezően rendelhették el közegészségi és közbiztonsági okokból védőoltások beadatását. Így történt 1902-ben is Cambridge-ben, amikor kitört a himlőjárvány. Az ügy felperese Henning Jacobson svéd származású lelkész volt, aki korábban, gyermekként szülőhazájában már kapott himlő elleni vakcinát, az oltás beadása után azonban súlyos mellékhatások jelentkeztek nála. Mivel utóbbira való hajlamot örökletesnek vélte, mind a saját, mind a gyermeke számára megtagadta a himlő elleni védőoltás beadatását, ami miatt eljárás alá vonták, és pénzbírságot szabtak ki vele szemben. Jacobson szerint ezzel az állam megsértette a szabadságát, valamint „észszerútlen, önkényes és elnyomó” bánásmódot alkalmazott vele szemben. Érvelését a Legfelsőbb Bíróság nem fogadta el, és 7:2 arányban kimondta, hogy Massachusetts szabályozása a Tizennegyedik Alkotmánykiegészítést nem sérti. A bíróság hangsúlyozta, hogy a társadalmi együttélés természetes velejárója, hogy az egyén érdeke és a köz érdeke olykor ütközik, és előfordulnak olyan súlyos veszéllyel fenyegető helyzetek, amikor az egyén szabadságát a köz érdekében korlátozásoknak kell alávetni. Továbbá a dön- 
tésben azt is kimondták, hogy a kötelező védőoltás elrendelése nem önkényes és elnyomó akkor, ha a közbiztonság észszerú érdeke úgy kívánja meg. A Legfelsőbb Bíróság elutasította a felperes arra irányuló érvelését, hogy egyes orvosi közösségek szintén ellenzik a vakcina beadatását, mivel szerintük az egyéb súlyos megbetegedéseket okoz; döntését a bírói fórum azzal indokolta, hogy az orvostudományi elméletek közötti választás nem a bíróságok, hanem a törvényhozó feladata.

Az ügy számos utóhatást váltott ki. Egyrészt a döntés megszületése után három évvel létrejött az Amerikai Oltásellenes Liga (Anti-Vaccination League of America), ${ }^{57}$ másrészt a döntés a Legfelsőbb Bíróság esetjogában precedensértékûvé vált, amit később többször is megerősítettek. Így például a Zucht v. King ügyben ${ }^{58} 1922$-ben, ahol a Legfelsőbb Bíróság kimondta, hogy az iskola járványügyi okokból megtagadhatja az olyan tanuló felvételét, aki egy kötelező védőoltást nem kapott meg. Mi több, a Jacobson v. Massachusetts ügy 2020-ban is visszaköszönt az egyik louisianai fellebbviteli bíróságon (United States Court of Appeals for the Fifth Circuit), ahol megállapítást nyert, hogy jogszerú az a texasi korlátozó rendelkezés, amely az abortuszokat, mint nem életmentô orvosi beavatkozásokat, elhalasztja a koronavírus-járvány terjedésének lassítása érdekében. ${ }^{59}$

A bemutatott jogesetek második csoportja a hadiállapot köré csoportosítható. A Legfelsőbb Bíróság e kérdéssel elsőként még az amerikai polgárháborúhoz kapcsolódóan, az Ex parte Milligan ügyben ${ }^{60}$ foglalkozott. A bíróság ítéletében megállapította, hogy a civilek felelősségre vonása katonai törvényszékek előtt alkotmányellenes mindaddig, amíg rendes bíróságok müködnek. Az ügy névadóját, Lambdin Milligant és társait kormány elleni összeesküvéssel, a Konföderáció támogatásával és lázítással vádolták, majd hármukat katonai törvényszék eloott akasztás általi halálra ítélték. Milligan védője a habeas corpus jogának megsértésére hivatkozott, majd az ügy a Legfelsőbb Bíróság elé került. Utóbbi kimondta, hogy a vádlottnak civilként joga van ahhoz, hogy bûncselekmény elkövetésének vádja miatt rendes bíróság előtt vonják felelősségre, mivel az alkotmány biztosítja az észszerütlen házkutatás és lefoglalás elleni védelmet, valamint megköveteli az alapos gyanúval alátámasztott letartóztatást és indokolt esetekben tárgyalás lefolytatását esküdtszék előtt. A bíróság nyomatékosan hangsúlyozta, hogy a katonai büntetőjog csak katonai mûveletekre alkalmazható és csak akkor, ha már a rendes bíróságok nem funkcionálnak. A Legfelsőbb Bíróság többségi véleménye abban is állást foglalt, hogy a habeas corpus felfüggesztésével az állampolgárokat legfeljebb fogva tartani lehet, azonban büntetőeljárás alá vonni vagy kivégezni őket nem.

57 The History of Vaccines, The Anti-Vaccination Society of America: Correspondence. Elérhető: www. historyofvaccines.org/content/blog/anti-vaccination-society-america-correspondence (Letöltve: 2020. december 10.).

58 U. S. Supreme Court, Zucht v. King, 260 U.S. 174.

59 U. S. Court of Appeals for the Fifth Circuit, No. 17-50060, Appeal from the U. S. District Court for the Western District of Texas, USDC No. 1:17-CV-690.

60 U. S. Supreme Court, Ex parte Milligan, 71 U. S. (4 Wall.) 2 (1866). 
Rendkívül vitatott esetei az amerikai Legfelsőbb Bíróságnak a Hirabayashi-ügy6 és a Korematsu-ügy, ${ }^{62}$ amelyeket későbbi döntéseiben felül is bírált az alkotmányvédő fórum. Mindkét eset a Pearl Harbor lebombázása utáni időkből való, amikor különösen erôteljessé vált a japánokkal szembeni idegengyúlölet az amerikai közvéleményben. A Hirabayashi-ügy előzménye volt, hogy miután az Egyesült Államok belépett a második világháborúba, Franklin $D$. Roosevelt elnök felhatalmazta a katonai parancsnokokat, hogy az általuk igazgatott katonai területekről bárkit kitiltsanak, ennek következtében pedig a parancsnokok a nyugati parton élő japán származású lakosokat (akkor is, ha egyébként amerikai állampolgárok voltak) kijárási tilalom és korlátozó intézkedések alá helyezték, végül pedig internálótáborokba küldték. Az ügy felperesét, Gordon Hirabayashit a kijárási tilalom megsértése miatt vonták felelősségre, aki ügyét a Legfelsőbb Bíróságig vitte. Utóbbi a felperes fellebbezését elutasítva kimondta, hogy egy kisebbségi nemzetiségi csoport tagjaival szembeni kijárási korlátozás elrendelése nem ütközik az alkotmányba akkor, ha az állam háborúban áll azon országgal, ahonnan ennek a nemzetiségi csoportnak a felmenői származnak.

A döntést csak még inkább beárnyékolta a bíróság egy évvel később, a Korematsu-ügyben meghozott, szintén mérföldkőnek számító ítélete. Az eset fókuszában ugyanaz a tényállás és probléma állt: Fred Korematsu 23 éves japán származású amerikai állampolgár megtagadta a kijelölt katonai terület elhagyását, arra hivatkozva, hogy az az Ötödik Alkotmánykiegészítésbe ütközik. A Legfelsőbb Bíróság döntésében akként érvel, hogy az Egyesült Államok kémkedéssel szembeni védelme mint közérdek áll ellentétben a japán származású amerikai állampolgár egyéni érdekével, és hogy mivel a kitiltást nem a felperes származása, hanem katonai szükségszerủség indokolta, így az nem ütközik az amerikai alkotmányba; a hadiállapot fennállása alatti effajta jogkorlátozás tehát nem alkotmányellenes. A Legfelsőbb Bíróság egyébként e döntését 2018-ban a Trump v. Hawaii ügyben ${ }^{63}$ (amelynek homlokterében az elnök azon végrehajtási utasítása állt, amely bizonyos, főképp muszlim vallású nemzetiségek számára megtiltotta a beutazást az országba akkor is, ha érvényes vízummal és úti okmánnyal rendelkeznek) hatályon kívül helyezte.

\section{A koronavírus-járvány miatt bevezetett különleges jogrend az Egyesült Államokban és a járványkezelésre adott szövetségi, tagállami és helyi szintứ válaszok}

A Covid-19-járvánnyal kapcsolatban először okvetlenül meg kell jegyezni, hogy a legfrissebb, 2020. december 15-i adatok alapján az Egyesült Államok jelenleg a világ legfertőzöttebb országa: 2020. január 21. óta több mint 17,5 millió beteget regisztráltak, és több mint 315 ezer 
ember hunyt el a betegségben. ${ }^{64} \mathrm{Az}$ ország újonnan megválasztott, 2021. januárban hivatalba lépő elnöke, Joe Biden a koronavírus elleni küzdelmet a legnagyobb kihívásnak nevezte, amivel az Egyesült Államoknak meg kell küzdenie a második világháború óta. Biden kampányának egyik visszatérő eleme volt a járvány minél hatékonyabb és átfogóbb kezelésének ígérete, amelynek keretében hangsúlyozta, hogy a Trump-adminisztráció által bevezetett intézkedéseket nem tartja elegendőnek. ${ }^{65}$ Ebből adódóan várható, hogy a jövő év elején beiktatandó elnök új politikai irányvonalat képvisel majd a járványkezelést illetően, ${ }^{66}$ mindazonáltal jelen elemzés csupán az eddig bevezetett intézkedéseket, az eddigi prioritásokat vizsgálja meg.

A koronavírus-járvány miatt az Egyesült Államokban először 2020. január 31-én hirdetett közegészségi veszélyhelyzetet az egészségügyért felelős miniszter az 1944. évi közegészségügyi ellátásokról szóló törvény ${ }^{67}$ alapján (amelyet azóta többször megújítottak). Ezt követően pedig, 2020. március 13-án az amerikai elnök kihirdette az országos veszélyhelyzetet is, részben a fenti törvényi rendelkezés, részben pedig az 1976. évi országos veszélyhelyzetrôl szóló törvény ${ }^{68}$ értelmében, amely országos veszélyhelyzet e sorok írásakor szintén hatályban van még. Azt mondhatjuk tehát, hogy a föderális szintú járványkezelés két alappillére az Egyesült Államokban a közegészségi veszélyhelyzet és az országos veszélyhelyzet párhuzamos kihirdetése volt.

Ugyanakkor az ország közigazgatási berendezkedéséből adódóan nemcsak e két, a szövetségi törvényhozástól származó különleges jogrendi kategória van egymással párhuzamosan hatályban, hanem mind a tagállamok, mind a helyi önkormányzatok jogosultak származékos jogalkotási hatáskörben - mintegy „vertikálisan” - különleges jogrendet kihirdetni és a válságkezeléssel kapcsolatosan szükséges jogszabályokat meghozni. Így a járványkezelés és ezzel összefüggésben a különleges jogrend szabályozása is erősen decentralizált az országban.

A válságkezelés az Egyesült Államokban általában véve helyi szintrôl indul, amelyet az illetékes tagállam kormányának támogatása, illetve súlyosabb veszélyhelyzetek esetén a szövetségi kormány támogatása egészíthet ki. ${ }^{69}$ Ellenben, a könnyebb megértés reményében, a járványkezelést e helyütt nem e logika szerint mutatjuk be, hanem a jogalkotási hatáskörök származásának iránya szerint haladunk: így a szövetségi alkotmányos és törvényi szintû rendelkezéseket vizsgáljuk meg először, majd pedig a tagállamok és a helyi önkormányzatok koronavírus-járványra adott válaszait vesszük sorra.

64 Centers for Disease Control and Prevention, United States COVID-19 Cases and Deaths by State. Elérhető: https://Covid.cdc.gov/Covid-data-tracker/\#cases_casesper1ook (Letöltve: 2020. december 15.).

65 A két elnökjelölt legutolsó, 2020. október 23-i vitája is a választási kampány véghajrájában javarészt a járványkezelési kérdések körül forgott. Elérhető: www.youtube.com/watch?v=yGPfKkjDIts (Letöltve: 2020. december 2.).

66 Lásd bővebben: Biden-Harris, The Biden Plan to Combat Coronavirus (COVID-19) and Prepare for Future Global Health Threats. Elérhetô: https://joebiden.com/Covid-plan/ (Letöltve: 2020. december 15.).

67 1944. évi közegészségügyi szolgáltatásokról szóló törvény 319. cikk (a) bekezdés.

68 1976. évi országos veszélyhelyzetről szóló törvény 201. cikk (a) bekezdés.

69 Lindsay-Webster, 2020. 
A szövetségi törvényhozás koronavírus-járványra adott válaszait illetően az Egyesült Államok alkotmánya kimondja, hogy a Kongresszus kizárólagos adókivetési hatáskört élvez az ország közös védelmének és általános jólétének biztosítása érdekében. ${ }^{70}$ Noha a katasztrófák elhárítása és a közegészségi veszélyhelyzetek kezelése szintén a Kongresszus hatáskörébe tartozik az olyan krízishelyzetekben, mint amilyen a koronavírus-járvány is, számos kongresszusi hatáskört átruházhatnak az elnökre azzal, hogy továbbra is a törvényhozás irányítja a szövetségi államok pénzügyi segélyeinek adminisztrációját és elosztását. ${ }^{71} \mathrm{Az}$ amerikai alkotmány továbbá főszabályként előírja, hogy a Pénzügyminisztérium csak akkor fordíthat közpénzt egy adott célra, hogyha azt előzetesen a Kongresszus előirányzatként jóváhagyta. ${ }^{72}$

Az Egyesült Államok költségvetése ${ }^{73}$ háromféle előirányzatot különböztet meg: szokásos előirányzatok (regular appropriations), folytatólagos ráfordítások (continuing resolutions) és kiegészítő előirányzatok (supplemental appropriations). Az olyan sürgősségi kiadások, mint a katasztrófák elhárításának és a közegészségi veszélyhelyzetek kezelésének finanszírozása, azaz az országos veszélyhelyzet miatt megállapított kiadások a kiegészítő előirányzatok kategóriájába tartoznak, és általában véve mentesülnek az egyéb, a fent említetten túli költségvetési korlátozások alól. ${ }^{74}$

A koronavírus-járvány kitörése óta a Kongresszus több olyan törvényt is elfogadott, amely a tagállamok, helyi önkormányzatok, vállalkozások és magánszemélyek járványkezelési költségeinek vagy a járvány miatt felmerült egyéb kiadásainak finanszírozását támogatja. Ezek a támogatások egyrészt a közegészségügyi ellátórendszer többletkiadásainak (például tesztelési infrastruktúra kialakítása és fenntartása) fedezését, másrészt a gazdaság élénkítését célozzák meg. A kifejezetten a koronavírus-járvánnyal összefüggésben elfogadott legfontosabb szövetségi törvények:

— a koronavírus miatti készültségről és kiegészítő előirányzatokról szóló törvény; ${ }^{75}$

— „a családok az elsők" törvény; ${ }^{76}$

— a koronavírus-segélyről, járványkezelésről és gazdaságvédelemről szóló törvény,77 valamint

— a fizetések védelméről és az egészségügyi ellátás színvonalának növeléséről szóló törvény. ${ }^{78}$

70 U. S. Const. art. I, \$ 8, cl. 1.

71 Elsea, J. K. et al., 2020.

72 U. S. Const. art. I, \$9, cl. 7 .

$73 \mathrm{Az}$ Egyesült Államok éves költségvetésének tervezetét az elnök készíti elő. Ezután a Kongresszus megtárgyalja a tervezetet, majd ezt alapul véve válaszként elkészíti a sajátját, amelyet visszaküld az elnöknek. A költségvetésre vonatkozó legfontosabb törvényi szabályokról lásd: Congressional Budget and Impoundment Control Act of 1974 (CBA) [2 U.S.C. \$\$ 601-688]; Balanced Budget and Emergency Deficit Control Act of 1985 (BBEDCA) [2 U.S.C. \$\$900-922].

74 Saturno-Heniff-Lynch, 2016.

75 Coronavirus Preparedness and Response Supplemental Appropriations Act [Pub. L. No. 116-123].

76 Families First Coronavirus Response Act (FFCRA) [Pub. L. No. 116-127].

77 Coronavirus Aid, Relief, and Economic Security Act (CARES Act) [Pub. L. No. 116-136].

78 Paycheck Protection Program and Health Care Enhancement Act [Pub. L. No. 116-139]. 
A törvények által bevezetett legfontosabb járványkezelési intézkedések az alábbiak szerint foglalhatók össze.

A 2020. március 5-én elfogadott, a koronavírus miatti készültségről és kiegészítő előirányzatokról szóló törvény 8,3 milliárd amerikai dollárt irányzott elő a járvány elleni küzdelem elsődleges lépéseire, így tesztelésre, védőoltással kapcsolatos kutatásokra, orvosi eszközök beszerzésére, továbbá az Egyesült Államok külképviseleteinek védelmére, esetleges evakuálására. Ezt követően, a 2020. március 18-án elfogadott „a családok az elsők” törvény elsősorban különböző szociális juttatásokról rendelkezik, így például fizetett betegszabadságról, adójóváírásról, Covid-19-tesztelésről, étkezési segélyezésről stb. A Kongresszus Költségvetési Irodája szerint csak ez a törvény 2030-ig mintegy 192 milliárd amerikai dollárral fogja megnövelni a költségvetési hiányt, amelyből a koronavírushoz kapcsolódó fizetett szabadságok és adójóváírások hozzávetőlegesen 105 milliárd dollárt tesznek majd ki. ${ }^{79}$ A 2020. március 27-én elfogadott, a koronavírus-segélyről, járványkezelésről és gazdaságvédelemről szóló törvény átfogó intézkedéscsomagot vezetett be a gazdaság, a közegészségügy, a tagállamok, a helyi önkormányzatok, a vállalkozások és a magánszemélyek megsegítése érdekében, és mintegy 2 billió (!) amerikai dollárt irányzott elő a Covid-19 elleni komplex küzdelemre. E törvény lehetôvé teszi, hogy a tagállamok meghatározott célokra fordítsák a szövetségi kormányzattól kapott pénzügyi támogatást, valamint kiegészítő munkanélküli segélyben részesíti a járvány miatt elrendelt kijárási korlátozás, karantén és munkahelybezárások miatt a „munkából kieső” munkavállalókat. Végül a 2020. április 23-án elfogadott, a fizetések védelméről és az egészségügyi ellátás színvonalának növelésérôl szóló törvény létrehozott egy pénzalapot a kisvállalkozások megsegítésére, és újabb közegészségügyi támogatásról rendelkezett; a törvény a március 27-én elfogadott átfogó intézkedéscsomaghoz képest további 484 milliárd amerikai dollárt irányzott elő a Covid-19 elleni védekezésre. (Érdekességként megjegyzendő, hogy e törvény a koronavírustesztek finanszírozását már önálló előirányzatként kezeli.)

A Kongresszuson túl a szövetségi végrehajtás is átfogóan reagált a Covid-19 által előidézett krízisre. A szövetségi minisztériumok (federal executive agencies) különös hatáskörú központi közigazgatási szervek, amelyek származékos jogalkotási hatáskörrel rendelkeznek. Utóbbi a Kongresszustól származik, amelyet a törvényhozó szerv a szövetségi közigazgatási eljárási törvény ${ }^{80}$ alapján ruházhat át a szövetségi minisztériumokra. ${ }^{81}$

A szövetségi minisztériumok rendes jogalkotási eljárása főszabály szerint kétféle lehet: formális és informális. Formális jogalkotásról akkor beszélünk, amikor a Kongresszus utasítja a szövetségi minisztériumot, hogy alkosson rendelet (statute) formájában új jogszabályt. Magát a jogalkotást egy úgynevezett közigazgatási bíró (administrative law judge) előtt tartott nyilvános vita előzi meg, ahol az érdekeltek előadhatják a jogszabályjavaslattal kapcsolatos

79 Swagel, 2020.

80 Administrative Procedure Act (APA) [5 U.S.C. \$\$ 500-596].

81 Price, 2020. 
észrevételeiket. ${ }^{82}$ Ennél azonban sokkal gyakoribb a szövetségi minisztériumokon belüli informális jogalkotás, amikor a minisztérium egy korábbi, általa meghozott rendeletet módosít vagy egészít ki. ${ }^{{ }^{3}}$ Ebben az esetben az érdekelteknek a formális jogalkotáshoz képest rövidebb idő áll rendelkezésükre, hogy előadják a jogszabályjavaslattal kapcsolatos ellenérveiket.

A formális és informális jogalkotási eljárások alól léteznek kivételek. Az egyik az, amikor a szövetségi minisztériumok sürgősségi jogszabályt (emergency rule) fogadnak el. Erre akkor adódik lehetőségük, amikor a rendes jogalkotási eljárás követése a közérdekkel ellentétben áll (például azért, mert sok időt vesz igénybe). ${ }^{84}$ A Covid-19 elleni fellépés keretében a szövetségi minisztériumok számos ilyen sürgősségi jogszabályt hoztak.

A rendes jogalkotási eljárások alóli egyéb kivételek a kongresszusi felülvizsgálati törvényben ${ }^{85}$ lelhetők fel. Utóbbi kimondja, hogy a szövetségi minisztériumoknak valamennyi újonnan elfogadott rendeletet meg kell küldeniük a Kongresszusnak, amelynek képviselőháza és szenátusa együttesen hozott közös rendelettel megsemmisítheti a szövetségi minisztériumok által elfogadott rendeleteket. Mindazonáltal ha e közös rendelet ellen az elnök vétót emel, a minisztériumi jogszabály hatályba léphet. A kongresszusi felülvizsgálati törvényben meghatározott másik kivétel az, hogy ha az egészséget vagy a biztonságot közvetlen veszély fenyegeti, akkor az elnök végrehajtási utasítással a minisztériumi rendeletet azonnal hatályba léptetheti. ${ }^{86} \mathrm{Mi}$ több, az elnök végrehajtási utasítással közvetlenül is elrendelheti, hogy a szövetségi minisztériumok egy jogszabályt vagy egy egyedi jogi aktust meghozzanak azzal, hogy a szövetségi közigazgatási eljárási törvény rendelkezéseit ilyen esetekben is be kell tartani. Noha az elnök végrehajtási utasítása alapján meghozott minisztériumi jogszabályok felülvizsgálatára a bíróságok jogosultak, a bírói gyakorlat meglehetôsen megengedő e téren: a szövetségi minisztériumoknak elég csupán az „észszerűség” fennállását bizonyítaniuk az általuk meghozott jogszabály jogszerüségének alátámasztásához. ${ }^{87}$

A szövetségi minisztériumok koronavírus-járványra adott válaszai közül érdemes számba vennünk néhányat. Így például a „családok az elsők” törvény felhatalmazta a Szövetségi Munkaügyi Minisztériumot, hogy a törvény által kiterjesztett fizetett munkavállalói távollét jó gyakorlatának részletszabályait kidolgozza. ${ }^{88}$ Vagy például a koronavírus-segélyről, járványkezelésről és gazdaságvédelemről szóló törvény feljogosította az Oktatási Minisztériumot, hogy döntsön a föiskolai és egyetemi hallgatók járvánnyal kapcsolatos nehézségei leküzdéséhez nyújtandó segélyekről. Úgyszintén, a fizetések védelmérôl és

82 Administrative Procedure Act $\$ \$ 556-557$.

83 Administrative Procedure Act $\$ 553$.

84 Administrative Procedure Act $\$ 553(\mathrm{~b})(\mathrm{B})$.

85 Congressional Review Act (CRA) [5 U.S.C. \$\$ 801-808].

86 Congressional Review Act $\$ 801(\mathrm{c})(2), \$ 801(\mathrm{c})(2)(\mathrm{A})$.

87 Brannon, 2018.

88 Families First Coronavirus Response Act $\$ 5111 ; 85$ Fed. Reg. 19,326 (Apr. 6, 2020). Elérhető: https://perma.cc/ FF93-MUZV (Letöltve: 2020. december 19.); corrected by 85 Fed. Reg. 20,156 (Apr. 10, 2020). Elérhető: https:// perma.cc/Z7TJ-7WFR (Letöltve: 2020. december 19.). 
az egészségügyi ellátás színvonalának növeléséről szóló törvény a Kisvállalkozások Hivatalát bízta meg, hogy utóbbi rendelkezzen az arra jogosult kisvállalkozásoknak járó közvetlen kifizetések folyósításáról. ${ }^{89}$

Az Egyesült Államok közigazgatási berendezkedéséből és a járványkezelésre vonatkozó szabályozás decentralizált jellegéból adódóan e helyütt a tagállami és helyi szintú szabályozást sem hagyhatjuk figyelmen kívül. A Tizedik Alkotmánykiegészítés ${ }^{90}$ az egyes hatáskörök szövetségi kormányzat, tagállamok és polgárok közötti megosztásáról rendelkezik. Eszerint ha az alkotmány egy hatáskört nem utal a szövetségi kormányzathoz, és annak a hatáskörnek a gyakorlását nem is tiltja meg a tagállamok számára, akkor az a hatáskör a tagállamokat illeti meg; ha pedig a tagállamok ezzel a hatáskörrel nem élnek, akkor a kérdés a polgárokra van bízva. A bíróságok a gyakorlatban a Tizedik Alkotmánykiegészítést úgy értelmezik, hogy a rendőrségi hatáskörök a tagállamokhoz tartoznak, így a közegészségi veszélyhelyzet okán elrendelt intézkedések elrendelése és betartatása is..$^{91}$

Ezzel összhangban a legtöbb tagállamban saját végrehajtási intézkedések vannak hatályban, amelyeket a tagállamok a szövetségi közigazgatási eljárási törvénnyel összhangban, saját közigazgatási eljárási törvényeik ${ }^{92}$ alapján dolgoznak ki. A közigazgatási eljárási törvényekben felsorolt hatáskörök mellett a tagállami alkotmányok is számos hatáskört utalnak a kormányzókhoz, akik e felhatalmazásukat a polgárok katasztrófáktól és veszélyhelyzetektôl való megóvása érdekében gyakorolhatják. Ekképpen a karantén vagy kijárási korlátozás elrendelése a kormányzók hatáskörébe tartozik, a végrehajtás foganatosítása pedig a tagállami egészségügyi hatóságok feladata.

E sorok írásakor az Egyesült Államok valamennyi, azaz mind az 50 tagállamában különleges jogrend van hatályban, amelyek elnevezése terminológiai sokféleségről árulkodik.93 Ami az alaki jogforrást illeti, a tagállami kormányzók rendszerint végrehajtási utasításokban hirdetik ki a különleges jogrendet. Utóbbira példaként hozható Ohio, ahol a kormányzó

89 Price, 2020.

90 U. S. Const. amend. X.

91 Galva-Atchison-Levey, 2005.

92 Például Washington State Administrative Procedure Act, Wash. Rev. Code $\$ 34.05$ (1988); Massachusetts State Administrative Procedure, Mass. Gen. Laws ch. 30A, \$\$ 1-25 (1954).

9328 tagállamban, például Alabamában, Dél-Karolinában, Kaliforniában, Hawaiin vagy Utahban veszélyhelyzeti állapot (state of emergency), 11 tagállamban, például Alaszkában, Arizonában, Louisianában vagy Új-Mexikóban közegészségi veszélyhelyzet (public health emergency), míg a legfertőzöttebb tagállamokban katasztrófahelyzet (disaster, disaster emergency vagy state of disaster emergency) van hatályban. Vannak tagállamok, amelyek egyedi különleges jogrendi terminológiát alkalmaznak. Így például Arkansasben veszélyhelyzetet (emergency), Maine-ben polgári veszélyhelyzetet (state of civil emergency), Minnesotában pedig békeidős veszélyhelyzetet (peacetime emergency) hirdettek ki. National Governors Association, Status of State COVID-19 Emergency Orders. Elérhető: www.nga.org/state-Covid-19-emergency-orders/ (Letöltve: 2020. december 15.). 
2020. márciusban veszélyhelyzeti állapotot hirdetett ki, ${ }^{94}$ és ennek megfelelóen a tagállam egészségügyi hatósága kijárási korlátozást vezetett be. ${ }^{95}$

Továbbá a tagállami különleges jogrend idôbeli hatályát tekintve azt mondhatjuk, hogy az általában az országos veszélyhelyzet fennállásához igazodik. Erre jó példa Montana kormányzójának végrehajtási utasítása, amely úgy rendelkezik, hogy a veszélyhelyzeti állapot a tagállamban addig tart, amíg az elnök a járványhelyzet miatti országos veszélyhelyzetet vissza nem vonja. ${ }^{96}$ Azonban a különleges jogrend határozott idejû́ elrendelésére is találunk példát: New York állam szabályozása szerint a katasztrófahelyzet 2021. április 21-ig marad hatályban. (Utóbbi egyébként megújítható.).7

Végül a helyi önkormányzatok járványkezelési intézkedéseiról kell még szólnunk. Az Egyesült Államokban a helyi önkormányzatok (local governments) megyékből (counties) és önkormányzatokból (municipalities) állnak. A megyékhez további kerületek (boroughs, parishes), az önkormányzatokhoz pedig városok (cities, towns) és települések (villages) tartoznak. A helyi önkormányzatok jogalkotási hatásköre a tagállamoktól ered, és e származékos jogalkotási hatáskörüket nem léphetik túl.98

Jóllehet a Tizedik Alkotmánykiegészítés rendelkezik a szövetségi állam és a tagállamok közötti hatáskörmegosztásról, a tagállamok és a helyi önkormányzatok közötti hatáskörmegosztásról egyáltalán nem szól, így újfent a Legfelsőbb Bíróság joggyakorlata mutathat irányt nekünk e kérdésben. Utóbbi a Hunter v. City of Pittsburgh ügyben ${ }^{99}$ megállapította, hogy „a helyi önkormányzatok a tagállamok alsóbb szintú politikai szervezeti egységei, olyan kiszolgáló szervek, amelyek a tagállam által rájuk ruházott kormányzati hatáskörök gyakorlására hivatottak [...] A helyi önkormányzatok számának, jellegének, múködésük időtartamának, valamint területi illetékességüknek a meghatározása a tagállamok abszolút diszkrecionális jogkörébe tartozik." A Legfelsőbb Bíróság ezen tételt később a Trenton v. New Jersey ügyben ${ }^{100}$ is fenntartotta, és kimondta, hogy „,kifejezett tagállami alkotmányos rendelkezés hiányában a helyi önkormányzatoknak nincsen olyan beleértett jogalkotási hatásköre, amely a tagállam által ráruházott kifejezett hatásköröket túllépi. A helyi önkormányzat csupán a tagállam egyik szervezeti egysége, és ha a tagállam úgy látja, akkor a helyi önkormányzat valamely hatáskörét visszatarthatja, visszavonhatja, vagy új hatáskört állapíthat meg számára. Legyen bármily' nagy vagy éppen kicsi a [helyi önkormányzat] cselekvési szabadsága, a tagállam teremtménye marad, amely a szuverén akarata által ráruházott ha-

94 Ohio Exec. Order No. 2020-01D (Mar. 9, 2020).

95 Director's Stay Safe Ohio Order, Ohio Dep't of Health (Apr. 30, 2020); Director's Order, Ohio Dep't of Health (July 7, 2020).

96 Mont. Exec. Order No. 2-2020 (Mar. 12, 2020); Mont. Exec. Order No. 3-2020 (Mar. 13, 2020).

97 N. Y. Exec. Order No. 202.60 (Sept. 4, 2020).

98 State \& Local Government, The White House. Elérhető: https://perma.cc/BLD9-C5DY (Letöltve: 2020. december 1.).

99 Hunter v. City of Pittsburgh, 207 U. S. 161, 178 (1907).

100 City of Trenton v. New Jersey, 262 U. S. 182, 187 (1923). 
tásköröket és privilégiumokat gyakorolja, illetve bírja.” A Legfelsőbb Bíróság precedensei alapján általánosságban elmondhatjuk, hogy a helyi kormányzatok csak a kifejezetten rájuk ruházott hatásköröket gyakorolhatják akkor, ha e hatásköröket szükségszerú és tisztességes hatáskör-átruházással delegálták rájuk, és amely hatáskörök a helyi kormányzat létezése szempontjából alapvetőnek bizonyulnak.

Ilyen, a járványkezelés szempontjából fontos helyi hatáskör az adókivetés, azon belül is az általános forgalmi adó kérdése. A New York State Association által közzétett kutatás ${ }^{101}$ becslései szerint csak New York államban 1,8 milliárd dolláros bevételkiesés várható 2020-ban a Covid-19 miatt visszaesett forgalom miatt. A helyi kormányzatok bevételkieséseinek kompenzációjára a korábban ismertetett szövetségi törvényeken túl még egy további, a képviselőház által előterjesztett törvényjavaslatot ${ }^{102}$ fontos megemlíteni, amelyet jelenleg éppen tárgyal a Kongresszus. E törvényjavaslat szerint további 179 milliárd dollárral támogatná a központi költségvetés a helyi önkormányzatokat. Egy másik, járványkezeléssel szervesen összefonódó helyi hatáskör az oktatás, pontosabban a távoktatás elrendelése. Miután utóbbi Philadelphiában bevezetésre került, a helyi iskolakörzetben az önkormányzat minden olyan tanulónak laptopot és ingyenes internet-hozzáférést biztosított, akiknek otthon addig nem volt (e költségek hozzávetőlegesen meghaladták a 11 millió amerikai dollárt). ${ }^{103}$ Harmadikként e helyütt a maszkviselés szabályozását emelnénk ki, amely szintén helyi önkormányzati hatáskört képez. A maszkviselés betartatása a városi rendőrkapitányságok és a sheriffek feladata. ${ }^{104}$ Végezetül érdekességként megemlítendő, hogy az Egyesült Államokban a helyi önkormányzatok múködésének egyik sajátossága a képviselö-testületek üléseinek nyilvánossága, így azokon bárki részt vehet. Utóbbi biztosítása a Covid-19-járvány idején ismételten újfajta kihívást keltett életre, amelynek megoldásaként a képviselő-testületek üléseit is áttették a virtuális térbe. ${ }^{105}$

\section{A különleges jogrend kihirdetésével kapcsolatos jogviták}

A különleges jogrend kihirdetésével kapcsolatos jogviták kapcsán elmondható, hogy a közegészségi veszélyhelyzet kapcsán számottevő precedensekről nem lehet beszámolni.

101 Marren-Acquario, 2020.

102 Heroes Act, H.R. 925, 116th Cong. (House engrossed amendment, Oct. 1, 2020).

103 School Year 2020-2021: Advancing Education Safely. School District of Philadelphia. Elérhető: https://perma.cc/ HYF6-QB5M; Chromebooks. School District of Philadelphia. Elérhető: https://perma.cc/KF6Q-TH67; Internet Access Options for Families. School District of Philadelphia. Elérhetô: https://perma.cc/FA57-A89V; Press Release. School District of Philadelphia, School District Will Use \$11 Million to Help Bridge the Digital Divide Among Students. Elérhető: https://perma.cc/J93L-DJD5 (Letöltve: 2020. december 15.).

104 Price, 2020.

105 Lásd erről bővebben például az észak-karolinai Asheville vagy az arizonai Surprise szabályozását: Asheville, N. C., Mun. Code pt. 1, art. II, \$9 (1985); McDaniel, 2020; Ord. No. 2020-12, City of Surprise, Arizona (Mar. 17, 2020); Ariz. Rev. Stat. \$38-431.01(A). 
(Az persze más kérdés, mint ahogyan már fentebb is utaltunk rá, hogy a 2020. évi választási kampány során a két elnökjelölt heves politikai vitákba bocsátkozott e kérdésben.) Mindazonáltal a közelmúlt eseményei egy szemléletes példával szolgálnak számunkra - még ha nem is a koronavírus-járvánnyal kapcsolatban -, ez pedig az Egyesült Államok déli határán épülő fal ügye.

Először is a vita jogi hátterét szükséges röviden felvillantani. Mint ahogyan láttuk, a korábban bemutatott országos veszélyhelyzetről szóló törvény kimondja, hogy amennyiben az elnök országos veszélyhelyzetet hirdet ki, a képviselőháznak minden hatodik hónapban felül kell vizsgálnia a veszélyhelyzet jogszerűségét, ha pedig az arra okot adó körülmények már nem állnak fenn, akkor kezdeményeznie kell a szenátusnál, hogy a veszélyhelyzetet együttes rendelettel szüntessék meg. Utóbbi rendelkezés a törvény elfogadása, azaz 1976 óta egészen a közelmúltig Csipkerózsika-álomban szendergett, amikor is Donald Trump országos veszélyhelyzetet hirdetett $\mathrm{ki}^{106}$ a déli országhatáron tervezett falépítéshez szükséges költségvetési finanszírozás biztosítása céljából, miután azt a Kongresszus, mint szokásos költségvetési előirányzatot (összege 5,7 milliárd amerikai dollár), korábban már kifejezetten elutasított. ${ }^{107}$ (A költségvetés elfogadásáról lásd bővebben a 3. pontot.) Ugyanakkor a Kongresszus által hozott országos veszélyhelyzetet megszüntető rendelet ellen Trump vétóval élt, így e veszélyhelyzet még jelenleg is hatályban van. ${ }^{108}$

Az eset élesen rámutat a szabályozás gyenge pontjaira. Egyrészt arra, hogy a veszélyhelyzet fogalmának tisztázatlansága és az intézkedésre jogosultnak juttatott rendkívül széles diszkrecionális jogkör zöld utat enged az elnöknek a törvény különböző politikai célokra történő felhasználására. Másrészt arra, hogy az elnöki vétó (és természetesen a korlátlan alkalommal való megújítás lehetoosége) gyakorlatilag lehetôvé teszi, hogy az elnök határozatlan időre rendelhesse el a veszélyhelyzetet. Harmadrészt az a probléma is megmutatkozik, hogy az elnök ezáltal szokásos költségvetési irányzatot vonhat el a Védelmi Minisztériumtól, ugyancsak politikai célokra. Az esetet valószínúsíthetően annak megosztó politikai karaktere és a közeledô választások miatt ellentétes szakirodalmi visszhangok kísérték. Így például Mark Tushnet, a Harvard Egyetem jogi karának professzora szerint az országos veszélyhelyzet alatt elköltött kiegészítő előirányzatok felhasználása tekintetében az elnöknek olyan széles mérlegelési jogköre van, hogy pozíciója még ebben a helyzetben is de iure sziklaszilárd lábakon áll. ${ }^{109}$

106 Declaring a National Emergency Concerning the Southern Border of the United States, Proc. 9844, February 15, 2019, 84 FR 4949-4950.

107 Halchin, 2020, 19. o.

108 Lásd bővebben: The Atlantic: The Alarming Scope of the President's Emergency Powers. Elérhető: www.theatlantic. com/magazine/archive/2019/01/presidential-emergency-powers/576418/ (Letöltve: 2020. december 15.).

109 NBC News, Fact Check: What's a 'National Emergency', Can Trump Declare One to Get His Wall? Elérhető: www.nbcnews.com/politics/donald-trump/fact-check-what-s-national-emergency-can-trump-declareone-n954966 (Letöltve: 2020. december 15.). 
Az eset egy másik érdekes aspektusa a magántulajdon kisajátításának kérdése - tudniillik a falépítési projektben megjelölt területek kétharmad része magánkézben van -, ugyanis a Legfelsőbb Bíróság korábban a Youngstown Sheet \&Tube Co. v. Sawyer ügyben ${ }^{110}$ megakadályozta, hogy Harry Truman elnök magántulajdonban lévő acélmúveket sajátítson ki veszélyhelyzetre hivatkozva. A bíróság érvelése szerint az acélmúvek kisajátításának feltétele, hogy a Kongresszus megszavazza ellentételezésként a kárpótlást mint rendes előirányzatot, a törvényhozó ezen hatáskörét pedig az elnök még veszélyhelyzet idején sem gyakorolhatja. Az eset tükrében érdekes elgondolkodni azon, hogyan döntene a Legfelsőbb Bíróság, ha jelen ügyben kellene állást foglalnia...

\section{5. Összegzés}

A modern alkotmányokkal és Magyarország Alaptörvényével ellentétben az Amerikai Egyesült Államok 1787-ben elfogadott alkotmánya és annak 27 alkotmánykiegészítése egyáltalán nem tartalmaz rendelkezéseket a különleges jogrendre nézve, amelynek példája szemléletesen illusztrálja, hogy a különleges állapotok alkotmányos szintú szabályozása nem szükségképpeni elvárás az alkotmányozóval szemben. Az USA-ban alkalmazott szabályozási megoldás dogmatikai értelemben az úgynevezett monista megközelítést követi, ami egyrészt azt eredményezi, hogy a különleges jogrendre vonatkozó szabályok az egyes jogszabályokban sporadikusan lelhetók fel, másrészt pedig azt, hogy a válaszreakciók tárháza majdnem végtelen, azaz az intézkedésre jogosult szerv, aki főszabály szerint az elnök, diszkrecionális jogköre rendkívül széles. Így tehát azt mondhatjuk, hogy míg hazánk az európai országokhoz hasonlóan a dichotóm modell mellett kötelezte el magát, az Egyesült Államok szabályozása teljesen más szabályozási logikát követ.

A magyar szabályozással szintén ellentétes megközelítést tükröz, hogy az amerikai alkotmány nem tekinthető kiindulópontnak a különleges jogrendet illetően, a vonatkozó törvényi rendelkezések taxatív számbavétele pedig gyakorlatilag lehetetlen vállalkozás - vagy legalábbis egy tematikus fókuszú könyvfejezet által kínált terjedelmi lehetôségeken messze túlmutató. Mindazonáltal jelentőségét tekintve valamennyi jogszabály közül kiemelkedik az 1976-ban elfogadott országos veszélyhelyzetről szóló törvény, amely - mint azt az Egyesült Államok déli határán épülő fal ügyében is láthattuk - lényegében véve biankó csekket ad az elnök kezébe a veszélyhelyzet elrendelését illetően. A veszélyhelyzet fogalmát a jogszabályban homály övezi, a szakirodalomban is csupán szótári, nem pedig jogalkotói vagy bírói értelmezéssel találkozhatunk. Ez utóbbi szintén idegen megoldás a magyar jogalkotó szemszögéből nézve, tekintve, hogy az Alaptörvény a különleges jogrend eseteit részletesen definiálja. Az országos veszélyhelyzetről szóló törvény 1979-es hatálybalépése óta összesen

110 U. S. Supreme Court, Youngstown Sheet \& Tube Co. v. Sawyer, 343 U.S. 579 (1952). 
69 alkalommal hirdettek ki az Egyesült Államokban országos veszélyhelyzetet, és ebből 40 (!) mind a mai napig hatályban van. És az országos veszélyhelyzetről szóló törvény csak egy a sok közül. A legfontosabbak közé sorolhatók továbbá az 1944. évi törvény a közegészségügyi szolgáltatásokról, az 1988. évi törvény a katasztrófavédelemről és a veszélyhelyzetben való segítségnyújtásról (az úgynevezett Stafford-törvény); az Egyesült Államok Kódexe; a 2002. évi törvény a belbiztonságról; valamint a 2006. évi törvény a Katrina hurrikán utáni veszélyhelyzet-kezelési reformról. Ezek a szövetségi törvények újabb különleges jogrendi esetköröket alkotnak, a gazdagítva a fogalmi diverzitást.

Valamennyi, a különleges állapotra vonatkozó törvényi szabályozást számba véve azt mondhatjuk, hogy az Egyesült Államok elnöke 136 (!) különféle jogkört gyakorolhat különleges jogrend idején, és akkor még nem beszéltünk azokról a hatáskörökről, amelyeket a Kongresszus, a szövetségi minisztériumok, a tagállami kormányok és a helyi önkormányzatok gyakorolhatnak különleges helyzetekben. Utóbbi sokfélesége értelemszerúen a hatalmas földrajzi kiterjedésú és népességú ország közigazgatási berendezkedésével is szoros összefüggésben áll, aminek eredménye, hogy nemcsak különféle szövetségi törvények lehetnek - akár ugyanazon tényállás alapján - egyszerre hatályban, hanem hogy vertikálisan is számos jogszabály vonatkozik az egyes tagállami és helyi szintú kérdésekre. Ez hazánkat tekintve ugyancsak elképzelhetetlennek tûnik, mivel a magyar közigazgatás centralizált jellegú.

Az amerikai és a magyar szabályozás közötti újabb elvi különbség, hogy az Egyesült Államokban a különleges jogrend meghosszabbítása egyáltalán nem számít „különlegesnek”. Ha csak az országos veszélyhelyzetrôl szóló törvényt vesszük ismét szemügyre, láthatjuk például, hogy az elsőként, 1979-ben Carter elnök által kihirdetett országos veszélyhelyzetet azóta is minden évben (!) megújították, számos más veszélyhelyzethez, például a 2001. szeptember 11-i terrortámadásokhoz kapcsolódóan kihirdetett veszélyhelyzethez hasonlóan.

Megállapíthatjuk tehát, hogy az amerikai modell mind a szabályozás koncepciója, decentralizációja, sokszínúsége, mind az ultima ratio jelleg hiánya, mind pedig az elrendelés határozatlan időtartama miatt teljesen eltér a magyar jogalkotó által alkalmazott keretektól.

Ami a koronavírus-járványt illeti, nem meglepő, hogy mivel az Egyesült Államok több mint 17 millió regisztrált fertőzöttel (2020. decemberi adat) a világ legfertőzöttebb országa, valamint mivel az országban 2020 novemberében elnökválasztást tartottak, a járványkezelés politikailag rendkívül szenzitív kérdést képez. Minthogy 2021. januárban a demokrata Joe Biden személyében (aki a leköszönő elnök, Donald Trump járványkezelési stratégiáját kampánya alatt végig hevesen bírálta) hivatalba fog lépni az ország 46. elnöke, a koronavírus miatt hozott intézkedések tekintetében is új irányvonalak várhatók. Mindazonáltal azt mondhatjuk, hogy a járványra válaszul adott eddigi erőfeszítéseket sem szabad alábecsülni.

A Covid-19 miatt az Egyesült Államokban először 2020. január 31-én hirdetett közegészségi veszélyhelyzetet az egészségügyért felelős miniszter az 1944. évi közegészségügyi ellátásokról szóló törvény alapján (amelyet azóta többször megújítottak). Ezt követően pedig, 2020. március 13-án az amerikai elnök bevezette az országos veszélyhelyzetet is, részben 
a fenti törvényi rendelkezés, részben pedig az 1976. évi országos veszélyhelyzetről szóló törvény értelmében, amely országos veszélyhelyzet e sorok írásakor szintén hatályban van még. Azt mondhatjuk tehát, hogy a föderális szintû̉ járványkezelés két alappillére az Egyesült Államokban a közegészségi veszélyhelyzet és az országos veszélyhelyzet párhuzamos kihirdetése volt.

A koronavírus-járvány a Kongresszust azonnali krízismenedzsmentre sarkallta, amelynek keretében elfogadták a koronavírus miatti készültségről és kiegészítő előirányzatokról szóló törvényt, „a családok az elsők” törvényt, a koronavírus-segélyről, járványkezelésről és gazdaságvédelemről szóló törvényt, valamint a fizetések védelméról és az egészségügyi ellátás színvonalának növeléséről szóló törvényt. A szövetségi törvényekről általában véve azt állapíthatjuk meg, hogy kettős célt szolgálnak: egyrészt az egészségügyi ellátórendszer felvértezését, másrészt a gazdaság élénkítését, a szociális ellátások kiterjesztését. Ezen törvények közül is kiemelkedik a koronavírus-segélyről, járványkezelésről és gazdaságvédelemről szóló törvény, amely átfogó intézkedéscsomagot vezetett be a gazdaság, a közegészségügy, a tagállamok, a helyi önkormányzatok, a vállalkozások és a magánszemélyek megsegítése érdekében, és mintegy 2 billió (!) amerikai dollárt irányzott elő a Covid-19 elleni komplex küzdelemre, amelynek keretében a járvány kezelésében a szövetségi minisztériumok, a tagállami kormányok és a helyi önkormányzatok is aktívan és összehangoltan részt vesznek. A járvány terjedésének lassításával kapcsolatos korlátozó intézkedések (például kijárási korlátozások, karantén, maszkviselés, távoktatás stb.) elrendeléséről általánosságban megállapítható, hogy rájuk nézve nem találhatunk rendelkezéseket a szövetségi szintú törvényekben, mivel azok teljes mértékben a tagállamok, illetve származékos jelleggel a helyi önkormányzatok hatáskörébe tartoznak. E helyütt megjegyzendő, hogy az amerikai szabályozás decentralizált jellege a magyar szabályozás erőteljesen centralizált jellegével újfent ellentétes képet mutat.

Végezetül fontos az alapjogok korlátozását illetően is néhány szót szólni, amely kérdésben az Egyesült Államok Legfelsőbb Bíróságának joggyakorlata kínál iránymutatást számunkra. (A magyar és az amerikai szabályozás közötti újabb eklatáns eltérésként hozható fel, hogy az amerikai alkotmány a magyar Alaptörvénnyel ellentétben nem rendelkezik a különleges jogrend idején történő alapjog-korlátozás szabályairól.) A releváns jogesetek halmazát két részhalmazra bonthatjuk, amelyek közül az egyik kifejezetten a járványkezeléshez, a másik pedig a hadiállapothoz kapcsolódik. És bár a hadiállapothoz fưzőőo jogkorlátozásra vonatkozó legfontosabb, úgynevezett Korematsu-tételét a bíróság 2018-ban, a Trump v. Hawaii ügyben hatályon kívül helyezte, a bírói fórum járványkezeléssel kapcsolatban tett 19. század eleji (!) megállapításai még ma is érvényesek. A Legfelsőbb Bíróság mérföldkőnek számító ítéleteiben kimondta, hogy a tagállamoknak hatáskörében áll a karantén elrendelése közegészségügyi okokból addig, amíg a Kongresszus ezzel ellentétes tartalmú jogszabályt nem hoz (Compaigne Francaise de Navigation a Vapeur v. Louisiana Board of Health ügy); továbbá kimondta, hogy a társadalmi együttélés természetes velejárója, hogy az egyén érdeke és 
a köz érdeke olykor ütközik, és előfordulnak olyan súlyos veszéllyel fenyegető helyzetek, amikor az egyén szabadságát a köz érdekében korlátozásoknak kell alávetni, valamint hogy a kötelező védőoltás elrendelése nem önkényes és elnyomó akkor, ha a közbiztonság észszerú érdeke úgy kívánja meg (Jacobson v. Massachusetts ügy); és végül, hogy az iskola járványügyi okokból megtagadhatja az olyan tanuló felvételét, aki egy kötelező védőoltást nem kapott meg (Zucht v. King ügy). A Legfelsőbb Bíróság utóbbi három megállapítása tehát jelen sorok írásakor is hatályban van; aktualitásukat mi sem mutatja jobban, hogy a Jacobson $v$. Massachusetts ügyre az egyik louisianai fellebbviteli bíróság 2020. áprilisban, a koronavírussal kapcsolatban elrendelt korlátozó intézkedések kapcsán is hivatkozott.

\begin{tabular}{|c|c|c|c|c|c|c|}
\hline 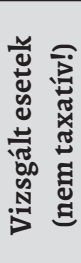 & 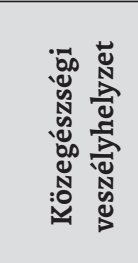 & 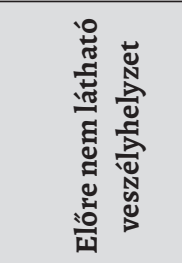 & 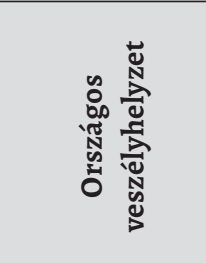 & 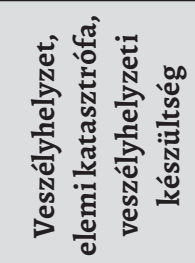 & 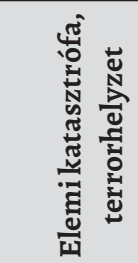 & 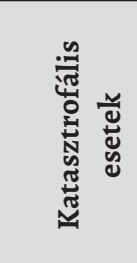 \\
\hline 卖. & \multicolumn{6}{|c|}{ Törvényi } \\
\hline 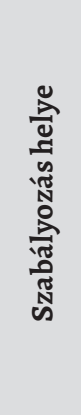 & $\begin{array}{l}\text { 1944. évi } \\
\text { közegész- } \\
\text { ségügyi } \\
\text { szolgálta- } \\
\text { tásokról } \\
\text { szóló } \\
\text { törvény }\end{array}$ & $\begin{array}{l}\text { Az Egyesült } \\
\text { Államok } \\
\text { Kódexe (1961) }\end{array}$ & $\begin{array}{l}\text { 1976. évi } \\
\text { országos ve- } \\
\text { szélyhelyzetről } \\
\text { szóló törvény }\end{array}$ & $\begin{array}{l}\text { 1988. évi } \\
\text { törvény } \\
\text { a katasztrófa- } \\
\text { védelemről és } \\
\text { a veszélyhely- } \\
\text { zetben való } \\
\text { segítségnyúj- } \\
\text { tásról }\end{array}$ & $\begin{array}{l}\text { 2002. évi } \\
\text { belbiz- } \\
\text { tonsági } \\
\text { törvény }\end{array}$ & $\begin{array}{l}\text { 2006. évi } \\
\text { Katrina } \\
\text { hurrikán } \\
\text { utáni } \\
\text { veszély- } \\
\text { helyzet- } \\
\text { kezelési } \\
\text { reformról } \\
\text { szóló } \\
\text { törvény }\end{array}$ \\
\hline
\end{tabular}




\begin{tabular}{|c|c|c|c|c|c|c|}
\hline 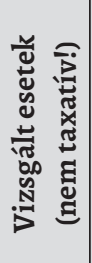 & 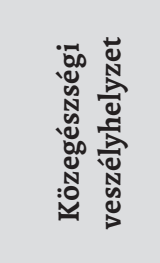 & 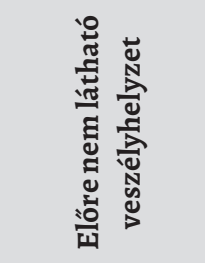 & 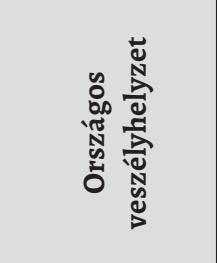 & 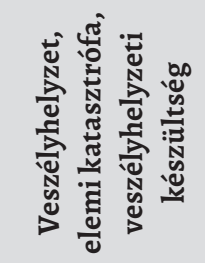 & 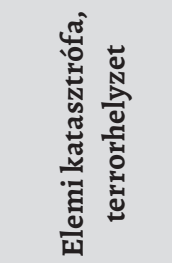 & 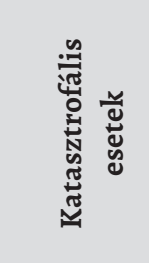 \\
\hline 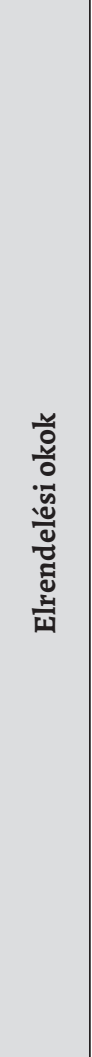 & $\begin{array}{l}\text { Változatos } \\
\text { okok, } \\
\text { nemcsak } \\
\text { betegségek, } \\
\text { hanem } \\
\text { például } \\
\text { a köz- } \\
\text { egészséget } \\
\text { sértő vagy } \\
\text { veszé- } \\
\text { lyeztető } \\
\text { természeti } \\
\text { kataszt- } \\
\text { rófák is } \\
\text { idetartoz- } \\
\text { hatnak. }\end{array}$ & $\begin{array}{l}\text { Az elrendelés } \\
\text { lehetséges oka } \\
\text { az előre nem } \\
\text { látható ve- } \\
\text { szélyhelyzet, } \\
\text { ám annak } \\
\text { fogalmát } \\
\text { a törvény } \\
\text { nem bontja } \\
\text { ki (szubszidi- } \\
\text { árius jellegú } \\
\text { szabályozás, } \\
\text { azaz csak } \\
\text { akkor lehet rá } \\
\text { hivatkozni, } \\
\text { ha a fegy- } \\
\text { verexport } \\
\text { ellenőrzé- } \\
\text { séról szóló } \\
\text { törvényben } \\
\text { használt } \\
\text { veszélyhely- } \\
\text { zet-fogalom } \\
\text { feltételei nem } \\
\text { teljesülnek). }\end{array}$ & $\begin{array}{l}\text { Rendkívül } \\
\text { széles diszkre- } \\
\text { cionális jogkör, } \\
\text { még arra sem } \\
\text { találhatunk } \\
\text { korlátozó ren- } \\
\text { delkezéseket, } \\
\text { hogy milyen } \\
\text { típusú társa- } \\
\text { dalmi vagy } \\
\text { természeti } \\
\text { jelenségek } \\
\text { idézhetnek elő } \\
\text { veszélyhely- } \\
\text { zetet. }\end{array}$ & $\begin{array}{l}\text { Az emberi élet } \\
\text { megóvása, } \\
\text { a tulajdon, } \\
\text { a közegészség } \\
\text { és a köz- } \\
\text { biztonság } \\
\text { védelme, } \\
\text { valamint } \\
\text { katasztrófa- } \\
\text { helyzet okozta } \\
\text { fenyegetés } \\
\text { csökkentése } \\
\text { vagy } \\
\text { elhárítása. }\end{array}$ & $\begin{array}{l}\text { Terrortá- } \\
\text { madások és } \\
\text { nukleáris } \\
\text { balesetek. }\end{array}$ & $\begin{array}{l}\text { Elemi ka- } \\
\text { tasztrófák }\end{array}$ \\
\hline & $\begin{array}{l}\text { Egész- } \\
\text { ségügyért } \\
\text { felelős } \\
\text { miniszter }\end{array}$ & Elnök & & & $\begin{array}{l}\text { Belbiz- } \\
\text { tonsági } \\
\text { miniszter }\end{array}$ & Elnök \\
\hline
\end{tabular}




\begin{tabular}{|c|c|c|c|c|c|c|}
\hline 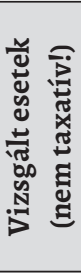 & 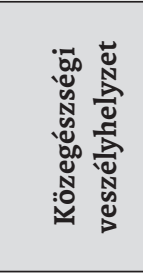 & 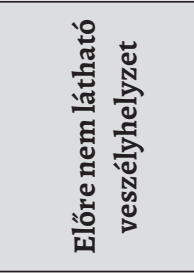 & 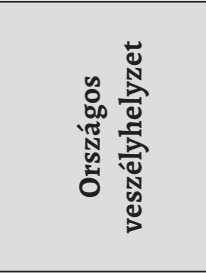 & 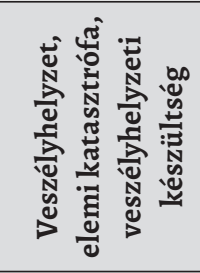 & 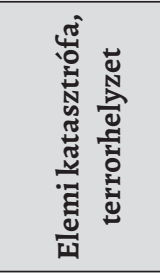 & 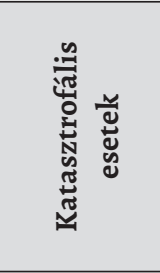 \\
\hline 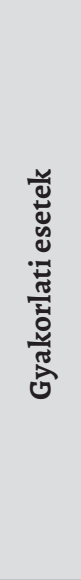 & $\begin{array}{l}\text { Csak } \\
2020 \text {-ban } \\
12 \text { alka- } \\
\text { lommal } \\
\text { hirdették } \\
\text { ki. }\end{array}$ & $\begin{array}{l}1988 \text { és } 2017 \\
\text { között } 57 \text { al- } \\
\text { kalommal hir- } \\
\text { dettek ki előre } \\
\text { nem látható } \\
\text { veszélyhely- } \\
\text { zetet. }\end{array}$ & $\begin{array}{l}\text { 1978-ban } \\
\text { történt hatály- } \\
\text { balépése óta } \\
\text { összesen } 69 \\
\text { alkalommal } \\
\text { hirdettek ki } \\
\text { országos ve- } \\
\text { szélyhelyzetet } \\
\text { az Egyesült } \\
\text { Államokban, } \\
\text { ebből pedig } \\
40 \text { (!) jelenleg } \\
\text { is hatályban } \\
\text { van. }\end{array}$ & $\begin{array}{l}1953 \text { és } \\
2014 \text { között } \\
\text { évente (!) } \\
\text { átlagosan } \\
\text { 35,5 elemi } \\
\text { katasztrófát } \\
\text { hirdettek ki. }\end{array}$ & $\begin{array}{l}\text { A kutatás } \\
\text { során } \\
\text { konkrét } \\
\text { példát nem } \\
\text { tártunk fel. }\end{array}$ & $\begin{array}{l}\text { A kutatás } \\
\text { során } \\
\text { konkrét } \\
\text { példát nem } \\
\text { tártunk } \\
\text { fel. }\end{array}$ \\
\hline
\end{tabular}

25. táblázat

Az Egyesült Államok különleges jogrendi szabályainak összegzése

Forrás: a szerző saját szerkesztése

\section{Irodalomjegyzék}

Brennan Center (2019) A Guide to Emergency Powers and Their Use [Online]. Elérhető: www. brennancenter.org/our-work/research-reports/guide-emergency-powers-and-their-use (Letöltve: 2020. december 6.)

Brennan Center (2020) Declared National Emergencies Under the National Emergencies Act [Online]. Elérhető: www.brennancenter.org/sites/default/files/2020-12/Declared\%20 Emergencies\%20under\%20NEA120820.pdf (Letöltve: 2020 . december 9.)

Brannon, V. C. (2018) Can a PresidentAmend Regulations by Executive Order? Cong. Res. Serv., LSB10172 (July, 18, 2018) [Online]. Elérhető: https://perma.cc/KFY7-ACMW (Letöltve: 2020. december 15.) Csink, L. (2017) 'Mikor legyen a jogrend különleges?', Iustum Aequum Salutare, 13(4), 7-16. o. ElSEA, J. K. et al. (2020) Emergency Authorities under the National Emergencies Act, Stafford Act, and Public Health Service Act. 1-2. Cong. Res. Serv., R46379 (updated July 14, 2020) [Online]. Elérhető: https://perma.cc/XLU5-55UN (Letöltve: 2020. december 7.)

FARKAS, Á., KELEMEN, R. (szerk.) (2020) Szkülla és Kharübdisz között. Tanulmányok a különleges jogrend elméleti és pragmatikus kérdéseiről, valamint nemzetközi megoldásairól. Budapest: Magyar Katonai Jogi és Hadijogi Társaság 
Galva, J. E., Atchison, C., Levey, S. (2005) Public Health Strategy and the Police Powers of the State. 120 Pub. Health Rep. 20, 21-22 (Supp. 1, 2005) [Online]. Elérhető: https://perma.cc/ H68H-5NKG (Letöltve: 2020 . december 11.)

Halchin, L. E. (2020) National Emergency Powers. Washington: Congressional Research Service, 1-25. o.

KahN, L. H., BARondess, J. A. (2008) 'Preparing for Disasters: Response Matrices in the USA and the UK', Journal of Urban Health, 85(6), 910-922. 0.

Killian, J. H. (1994) The Constitution of the United States of America [Online]. Elérhető: www. senate.gov/civics/resources/pdf/US_Constitution-Senate_Publication_103-21.pdf (Letöltve: 2020. december 1.)

Lindsay, B., WebsteR, E. (2020) Congressional Primer on Responding to and Recovering from Major Disasters and Emergencies 1-2. Cong. Res. Serv., R41981. (updated June 3, 2020) [Online]. Elérhető: https://perma.cc/EDH5-ATYE (Letöltve: 2020. december 7.)

Marren, J. F., ACQuario, S. J. (2020) Lost Revenue and State Aid Cuts: Coronavirus Economic Impact on Counties 3. New York State Association of Counties (May 2020) [Online]. Elérhetô: https://perma.cc/EPN7-YZ8Z (Letöltve: 2020. december 15.)

MCDaniel, P. (2020) Asheville City Council Meeting to Be Held Following CDC, State and Local Guidelines. City of Asheville (Mar. 21, 2020) [Online]. Elérhető: https://perma.cc/H4WZ-J664 (Letöltve: 2020. december 15.)

MÉszÁros, G. (2016) 'A „szabályozatlan” kivételes állapot amerikai modellje: tévút vagy követendő példa?' Fundamentum, 2016/2-4, 37-55. o.

MÉszÁros, G. (2017) Különleges helyzetek és beavatkozási lehetôségek az alkotmányos demokráciákban (PhD-értekezés). Debrecen: Debreceni Egyetem Marton Géza Állam- és Jogtudományi Doktori Iskola

PRICE, A. (2020) Federal, State and Local Government Responses to COVID-19. Library of Congress (November 2020) [Online]. Elérhetô: www.loc.gov/law/help/Covid-19-responses/us.php\#_ ftn95 (Letöltve: 2020. december 15.)

RaISZ, A. (2010) 'Az emberi jogok amerikaközi védelme', Publicationes Universitatis Miskolcinensis Sectio Juridica et Politica, 28(1), 281-295. o.

Saturno, J. V., Heniff JR., B., LYNCH, M. S. (2016) The Congressional Appropriations Process: An Introduction 19. Cong. Res. Serv., R42388 (updated Nov. 30, 2016) [Online]. Elérhető: https:// perma.cc/2K5A-JNPT (Letöltve: 2020. december 19.)

SwAGEL, P. L. (2020) Congressional Budget Office, Preliminary Estimate of the Effects of H.R. 6201, 1-2 (Apr. 2, 2020) [Online]. Elérhető: https://perma.cc/6XNU-5GAV (Letöltve: 2020. december 10.)

Till, Sz. (2019): 'Különleges jogrend' in Jakab, A., Fekete, B. (szerk.) Internetes Jogtudományi Enciklopédia [Online]. Elérhető: http:/lijoten.hu/szocikk/kulonleges-jogrend (Letöltve: 2020. december 11.)

Тóтн, Z. J. (2017) 'Az Egyesült Államok alkotmányának kartális és történeti jellege’, Polgári Szemle, 13(4-6), 219-233. o.

VARGA Zs., A. (2015) Eszménybőlbálvány? A joguralom dogmatikája. 1. kiadás. Budapest: Századvég 